\title{
The Role of Catalysts in Biomass Hydrothermal Liquefaction and Biocrude Upgrading
}

\author{
Ayaz Ali Shah ${ }^{1,2}$, Kamaldeep Sharma ${ }^{1} \mathbb{D}$, Muhammad Salman Haider ${ }^{1}$, Saqib Sohail Toor ${ }^{1}$, \\ Lasse Aistrup Rosendahl ${ }^{1}$, Thomas Helmer Pedersen ${ }^{1}$ and Daniele Castello ${ }^{1, * \mathbb{D}}$ \\ 1 AAU Energy, Aalborg University, Pontoppidanstræde 111, 9220 Aalborg Øst, Denmark; \\ aas@duet.edu.pk (A.A.S.); ksh@energy.aau.dk (K.S.); mush@energy.aau.dk (M.S.H.); \\ sst@energy.aau.dk (S.S.T.); lar@energy.aau.dk (L.A.R.); thp@energy.aau.dk (T.H.P.) \\ 2 Department of Energy \& Environment Engineering, Dawood University of Engineering and Technology, \\ New M.A Jinnah Road, Karachi 74800, Pakistan \\ * Correspondence: dac@energy.aau.dk
}

Citation: Shah, A.A.; Sharma, K.; Haider, M.S.; Toor, S.S.; Rosendahl, L.A.; Pedersen, T.H.; Castello, D. The Role of Catalysts in Biomass

Hydrothermal Liquefaction and Biocrude Upgrading. Processes 2022, 10, 207. https://doi.org/10.3390/ pr10020207

Academic Editor: Francesca Raganat

Received: 13 December 2021

Accepted: 18 January 2022

Published: 21 January 2022

Publisher's Note: MDPI stays neutral with regard to jurisdictional claims in published maps and institutional affiliations.

Copyright: (C) 2022 by the authors. Licensee MDPI, Basel, Switzerland. This article is an open access article distributed under the terms and conditions of the Creative Commons Attribution (CC BY) license (https:// creativecommons.org/licenses/by/ $4.0 /)$.

\begin{abstract}
Hydrothermal liquefaction (HTL) of biomass is establishing itself as one of the leading technologies for the conversion of virtually any type of biomass feedstock into drop-in biofuels and renewable materials. Several catalysis strategies have been proposed for this process to increase the yields of the product (biocrude) and/or to obtain a product with better properties in light of the final use. A number of different studies are available in the literature nowadays, where different catalysts are utilized within HTL including both homogeneous and heterogeneous approaches. Additionally, catalysis plays a major role in the upgrading of HTL biocrude into final products, in which field significant developments have been observed in recent times. This review has the ambition to summarize the different available information to draw an updated overall picture of catalysis applied to HTL. The different catalysis strategies are reviewed, highlighting the specific effect of each kind of catalyst on the yields and properties of the HTL products, by comparing them with the non-catalyzed case. This allows for drawing quantitative conclusions on the actual effectiveness of each catalyst, in relation to the different biomass processed. Additionally, the pros and cons of each different catalysis approach are discussed critically, identifying new challenges and future directions of research.
\end{abstract}

Keywords: HTL; biocrude; catalysts; hydrotreating; hydroprocessing

\section{Introduction}

Fossil fuels are declining rapidly due to their excessive use and increase in global industrialization. Therefore, it is necessary to develop not only renewable and environmental friendly but also economical energy sources for the production of sustainable fuels and chemicals [1,2]. Due to the absence of competition for land use and water resources, low value feedstocks such as forest residues, agricultural residues, sewage sludge, and municipal solid waste are promising and the most widely available resources for the production of green fuels. Currently, biofuels derived from organic matters or plant biomass are the only sustainable carbon source for the production of liquid fuels and well-suited to the existing transport infrastructure [3,4]. Through the implementation of effective production processes, biofuels can generate less greenhouse gases (GHGs) compared to fossil fuels [5-7].

Direct combustion, gasification, pyrolysis, and hydrothermal liquefaction (HTL) are the most developed thermochemical technologies, which can produce heat, syngas $\left(\mathrm{H}_{2}\right.$ and $\mathrm{CO}$ ), and biocrude oil, respectively, through the conversion of various biomass. However, combustion, gasification, and pyrolysis are energy intensive processes due to pre-drying of feedstocks with higher water content $[2,8]$. Therefore, hydrothermal liquefaction (HTL) is a promising technology, which is potentially able to convert higher water content feedstocks into considerably lower oxygen content and higher calorific value biocrude oil without 
demanding a preliminary drying step of the biomass. In the HTL process, wet biomass is processed at high temperatures $\left(250-450{ }^{\circ} \mathrm{C}\right)$ and high pressures $(100-350$ bar) in the presence of water. Water as a solvent presents several advantages close to its critical point such as lower viscosity and dielectric constant, leading to better solubility of organic compounds, while catalytic activity for acid-base reactions increases due to the increase in its ionic product. During HTL, the oxygen present in the feedstock is partly removed by dehydration and decarboxylation reactions, producing $\mathrm{CO}_{2}, \mathrm{CO}$, and $\mathrm{H}_{2} \mathrm{O}$. Despite the better quality of biocrude, oxygen content is still high and results in a highly viscous and unstable biocrude. For the replacement of transportation fuel, successful hydrotreating is required for the upgrading of biocrude $[9,10]$. Many informative reviews are accessible in the literature in which many research efforts have been dedicated to the production of biocrude through the HTL process and investigated the influence of various process variables such as temperature, pressure, catalyst, retention time, and biomass:water ratio on HTL products [10-18].

Research activities on HTL are highly focused on the use of various homogeneous and heterogeneous catalysts to enhance biocrude yield and quality simultaneously. This review paper aims to provide a dedicated review on the effects of homogeneous and heterogeneous catalysts on HTL products as well as biocrude upgrading. This study will increase awareness regarding the impact of these catalysts during the HTL conversion of various feedstocks and biocrude upgrading. Several catalysts have been employed on various biomass feedstocks. The catalyst role is highly linked with several process parameters such as temperature, retention time, and the chemical composition of feedstock and biocrude. In this review paper, alkali salts, organic acids, transition metals, metal oxides, and activated carbon were investigated in the category of homogeneous and heterogeneous catalysts, respectively. For the upgrading of biocrude, some commercial catalysts were also studied. In this work, potential solutions are also proposed to identify the challenges and research needs.

\section{Catalysis during HTL}

The role of a catalyst for biomass processing in HTL to enhance biocrude yield and quality is intensely dependent upon several factors such as temperature, residence time, reactor system, etc. $[12,19,20]$. Among them, temperature is the most dominant operating parameter for HTL. Many studies have proven that temperature strongly affects the biocrude yield and elemental composition [21-25]. The overall temperature range for HTL varies from 270 to $400{ }^{\circ} \mathrm{C}$ [10]. Regardless of feedstock type, many studies show that biocrude yield increases with the rise in temperature (from 280 to $350^{\circ} \mathrm{C}$ ); however, a further increase in temperature generally decreases the biocrude yield [21,26-28]. In the majority of cases, the catalysts were applied in a subcritical temperature range $\left(270-350^{\circ} \mathrm{C}\right)[29-34]$, except in a few studies, where the catalyst effects in supercritical temperature $\left(>373.94{ }^{\circ} \mathrm{C}\right)$ were explored [28,35-41]. All these authors stated different conclusions depending on the nature and type of catalyst employed.

Moderate temperatures $\left(300-350{ }^{\circ} \mathrm{C}\right)$ facilitate the hydrolysis of biomass, condensation, and repolymerization of reactive substances to form biocrude [30,42]. However, temperatures above the critical point $\left(373.94^{\circ} \mathrm{C}\right)$ improve the degree of deoxygenation and offer higher HHVs [36]. Retention time (RT) is another important parameter, longer residence time, higher than $10 \mathrm{~min}$, mostly increases the biocrude yield, however, above the threshold level, biocrude yield decreases on account of higher organic loss in the form of water-soluble organics to the aqueous phase or gases by cracking reactions [14]. Xu et al. stated the possible reasons behind the leveling off or decreasing the biocrude yield at prolonging retention times, which include cracking of biocrude components to gases, repolymerization to form char, and condensation to aqueous products [43]. Malins et al. used a catalyst $\left(\mathrm{FeSO}_{4}\right)$ for sewage sludge at $300^{\circ} \mathrm{C}$ in an autoclave under reaction times of 10 to $100 \mathrm{mins}$ and reported a maximum biocrude yield of $48 \%$ at $40 \mathrm{~min}$. On the other hand, prolonged RTs enhance the gaseous products, and the biocrude quality is improved through 
intermingling tar substances with biocrude that could positively affect the HHV [26]. Seehar et al. derived a different conclusion by conducting a catalytic $\left(\mathrm{K}_{2} \mathrm{CO}_{3}\right)$ reaction time study on eucalyptus at $350^{\circ} \mathrm{C}$ from $10 \mathrm{~min}$ to $25 \mathrm{mins}$ and reported that $15 \mathrm{~min}$ is the best reaction time for the eucalyptus conversion [27]. Another study indicated that $10 \mathrm{~min}$ is the optimum RT for the HTL of lignocellulosic biomass (Cunninghamia lanceolata) at $320^{\circ} \mathrm{C}$ [44].

The reactor system also influences the overall energy recovery of the HTL system, typically, longer RTs are selected for autoclave-based reactors that give slightly lower yields due to lower heating rates $[23,24,26]$. Alternatively, improved biocrude productivity has been observed by many studies adopting micro-batch reactors. Even so, shorter RTs in the range of 10 to $20 \mathrm{~min}$ are declared as ideal for biomass liquefaction in all micro-batch reactor-oriented systems $[14,27,28,45]$.

Numerous catalysts have been tested with a variety of biomass aiming to improve both biocrude yield and quality $[14,15,18,20,46]$. In the broader spectrum, catalysts have been classified into two types:

(1) Homogenous catalysts including alkaline salts [27,32,36,47], and organic acids [42,48-50]; and

(2) Heterogeneous catalysts such as transition metals $\mathrm{Ni}, \mathrm{Cu}, \mathrm{Fe}$, metal oxides [18], $\mathrm{CoMo} / \mathrm{Al}_{2} \mathrm{O}_{3}$, and activated carbon [51], etc.

\section{Methodology}

Understanding the influence of the catalyst on the HTL products may be complicated. Indeed, catalysts affect several outputs of the process, resulting in variations in both the quantity and quality of the produced biocrude. Indeed, an important aim of catalysis is that of maximizing the yield of biocrude, reducing the production of other reaction products such as char, gases, and water-soluble compounds. Maximizing the amount of produced biocrude is a fundamental point as it determines the economy of the process.

On the other hand, another scope of catalysis is that of improving the "quality" of biocrude by obtaining a product that presents a reduced amount of oxygen, nitrogen, and other heteroatoms, which could therefore be upgraded with reduced efforts. This can be quantified by the higher heating value (HHV): an increased value of HHV is directly related to a reduced amount of heteroatoms.

These two tendencies (i.e., yield improvement and HHV improvement) do not necessarily take place at the same time, which makes it difficult to evaluate whether catalysis is advantageous or not. However, it could be stated that a successful catalytic process should be able to increase the share of biomass energy that is transferred into biocrude. This can be quantified by the so-called "energy ratio" (ER), defined as:

$$
\mathrm{ER}=\frac{\mathrm{Y}_{\text {biocrude }} \cdot \mathrm{HHV}_{\text {biocrude }}}{\mathrm{HHV}_{\text {feed }}}
$$

where $Y_{\text {biocrude }}$ is the mass yield of biocrude from the HTL process and $H H V_{\text {biocrude }}$ and $\mathrm{HHV}_{\text {feed }}$ are the higher heating values of the produced biocrude and of the biomass feedstock, respectively, both on dry ash-free basis.

In the following sections, catalytic HTL is analyzed by comparing the ER of the noncatalytic vs. catalytic experiments, based on the data reported in the literature. Catalysis will then be advantageous if it is able to increase ER with respect to the non-catalyzed case.

Moreover, in order to provide full data to the reader, each analyzed catalytic experiment the values of yield before and after catalysis will be reported, along with the relative change of yield and the absolute changes in carbon and nitrogen content and in HHV.

\section{Homogenous Catalysts for HTL}

Homogenous catalysts are those that can easily be dissolved in the water phase. Homogeneous catalysts include carbonates and hydroxides of alkali metals ( $\mathrm{Na}, \mathrm{K}, \mathrm{Ca}$, etc.). Besides alkalis, acids such as formic acid, acetic acid, hydrochloric acid, sulfuric acid, and their solutions are widely accepted as homogenous catalysts [52]. Homogenous catalysts 
are advantageous as these are inexpensive and easily accessible and effective agents for suppressing char formation. In parallel, some drawbacks are also present, for instance, their recovery after reaction could be difficult due to their higher degree of solubility in the aqueous phase $[15,19]$. Moreover, alkali hydroxides are often corrosive to the reactor system, which can be managed by selecting an appropriate anti-corrosive material for the HTL reactor [53].

\subsection{Alkali and Alkali-Earth Catalysts}

Over the years, alkali catalysts have been proved promising for enhancing the biocrude yield and quality [54]. Alkali catalysts improve the conversion of biomass through a higher extent of depolymerization, deoxygenation, desulfurization, and denitrogenation, which results in a lower concentration of heteroatoms in the biocrude [55,56]. Along with these advantages, alkali catalysts are strong promoters for water gas shift reactions and suppress the formation of char [12,57]. Although this is more challenging for high lignin containing biomass, in which a high amount of char is obtained, which could relate to its polyaromatic ring structure [57]. To explore the role and reactivity of catalysts with carbohydrates, proteins, and lipids, here, different type of biomass such as lignocellulosic [27,31,32,35], manures [36,58], microalgae [29,30,42,59], sewage sludge [22,28,36], and model compounds $[29,60]$ are selected.

Several studies have reported that alkali catalysts are favorable for lignocellulosics and carbohydrate-rich biomass [27,61-63]. However, the studies for biomass containing higher portions of proteins ( $>50 \%$ ) and lipids ( 7 to $30 \%$ ) state different conclusions based on the proportion of carbohydrates [29,64-67]. In nitrogen-containing feedstocks, the peptide linkages in proteins are more stable than the carbohydrates, thus alkaline hydrolysis does not promote efficient cleavage of peptide linkages as compared to glycosidic bonds [48]. Jindal et al. liquefied wood at $280{ }^{\circ} \mathrm{C}$ for 15 min with four alkali catalysts: $\mathrm{K}_{2} \mathrm{CO}_{3}, \mathrm{Na}_{2} \mathrm{CO}_{3}, \mathrm{KOH}$, and $\mathrm{NaOH}$. They noticed a maximum biocrude yield of $34 \%$ with $\mathrm{K}_{2} \mathrm{CO}_{3}$ (approximately twice the non-catalytic yield). The overall conversion rate was found in the order: $\mathrm{K}_{2} \mathrm{CO}_{3}>\mathrm{KOH}$ $>\mathrm{Na}_{2} \mathrm{CO}_{3}>\mathrm{NaOH}$ [31]. Potassium salts are known for repolymerization of the organic fragments, escalating the non-polarity of biocrude, which results in easy separation of the biocrude phase from the water. Additionally, unlike metal hydroxides, potassium salts do not cause corrosion $[12,68]$. Zhu et al. reported a significant increase in biocrude yield from 18 to $35 \%$ with $\mathrm{K}_{2} \mathrm{CO}_{3}$ (almost two-fold with respect to non-catalytic run).

The catalyst $\left(\mathrm{K}_{2} \mathrm{CO}_{3}\right)$ reacts with water and develops its associated bicarbonate compounds, which can be termed as a secondary promoter for biomass degradation. The alkaline environment raises the $\mathrm{pH}$ level and speeds up the conversion process. Equations (2) and (3) describe the equilibria involved during $\mathrm{K}_{2} \mathrm{CO}_{3}$ dissolution in water [69]:

$$
\begin{aligned}
& \mathrm{K}_{2} \mathrm{CO}_{3}+\mathrm{H}_{2} \mathrm{O} \rightarrow \mathrm{KHCO}_{3}+\mathrm{KOH} \\
& 2 \mathrm{KHCO}_{3} \rightarrow \mathrm{H}_{2} \mathrm{O}+\mathrm{K}_{2} \mathrm{CO}_{3}+\mathrm{CO}_{2}
\end{aligned}
$$

Bi et al. [70] processed pretreated sorghum bagasse at 300 to $350{ }^{\circ} \mathrm{C}$ with alkali $\left(\mathrm{K}_{2} \mathrm{CO}_{3}\right.$, $\mathrm{KOH}$ ) and compared it with different heterogeneous catalysts ( $\mathrm{Ni} / \mathrm{Si}-\mathrm{Al}, \mathrm{Ni}_{2} \mathrm{P}$, and zeolite). $\mathrm{K}_{2} \mathrm{CO}_{3}$ turned out to be the most efficient catalyst, being able to improve the biocrude yield to $61 \%$ : three times higher compared to the non-catalytic run [71]. In alkaline conditions, the macromolecules of lignocellulosic biomass (i.e., cellulose, hemicellulose and lignin) undergo different chemical reactions. The first is hydrolysis, which produces monomers and oligomers such as glucose, guaiacol, fructose, etc. These monomers are further broken down into lower molecular weight intermediates, which may become part of the biocrude or aqueous phase. During HTL, free radicals are formed. If the hydrogen content is not sufficient enough to stabilize the free radicals, then these free radicals tend to associate with each other and form char (e.g., via repolymerization of 5-hydroxymethyl-furfural $(\mathrm{HMF})$ ) [70]. Detailed information on the effects of different homogenous catalysts on biocrude properties is given in Table 1. 
Table 1. Effects of homogenous catalysts on biocrude yield, carbon, and HHVs.

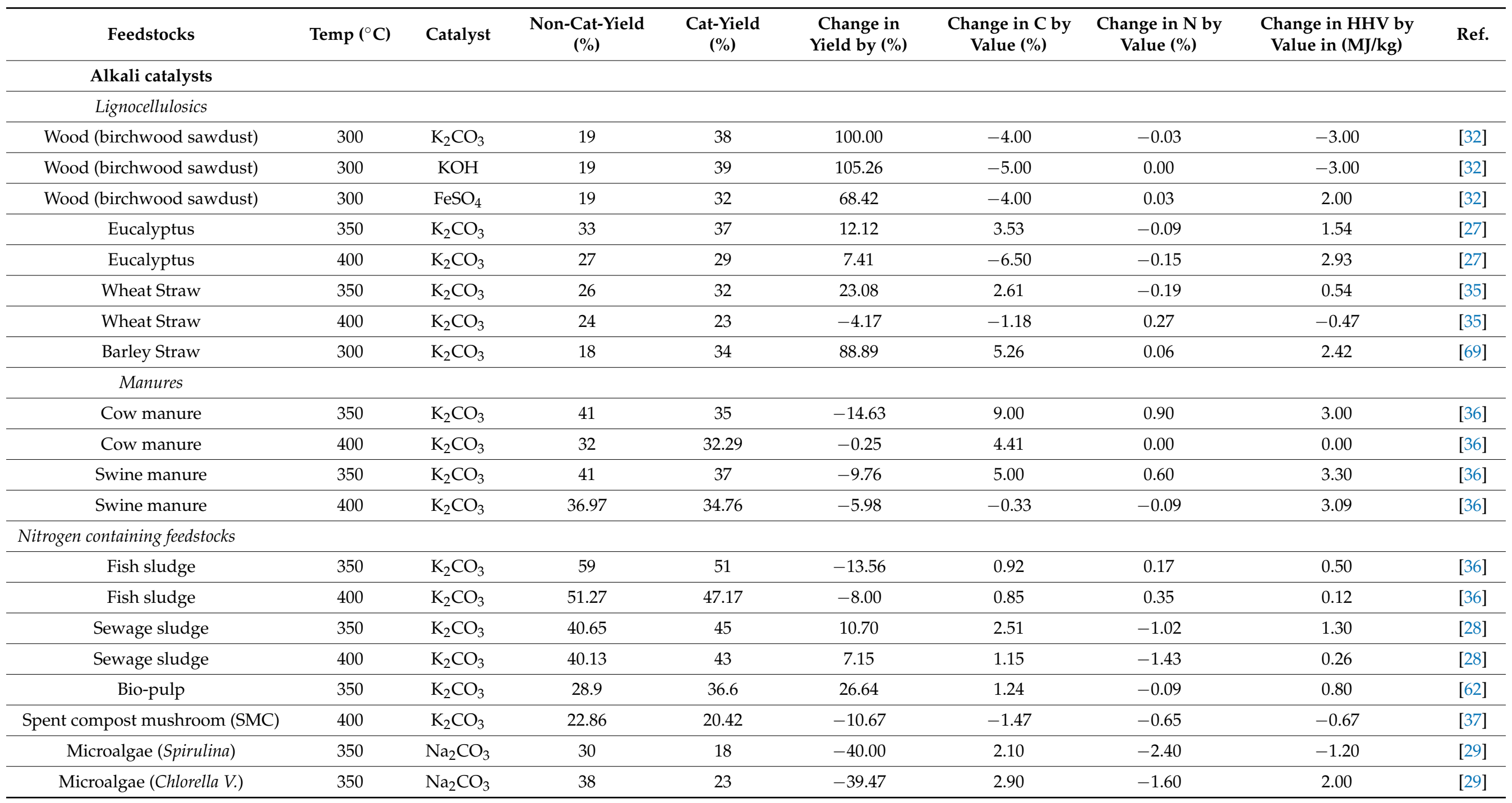


Table 1. Cont.

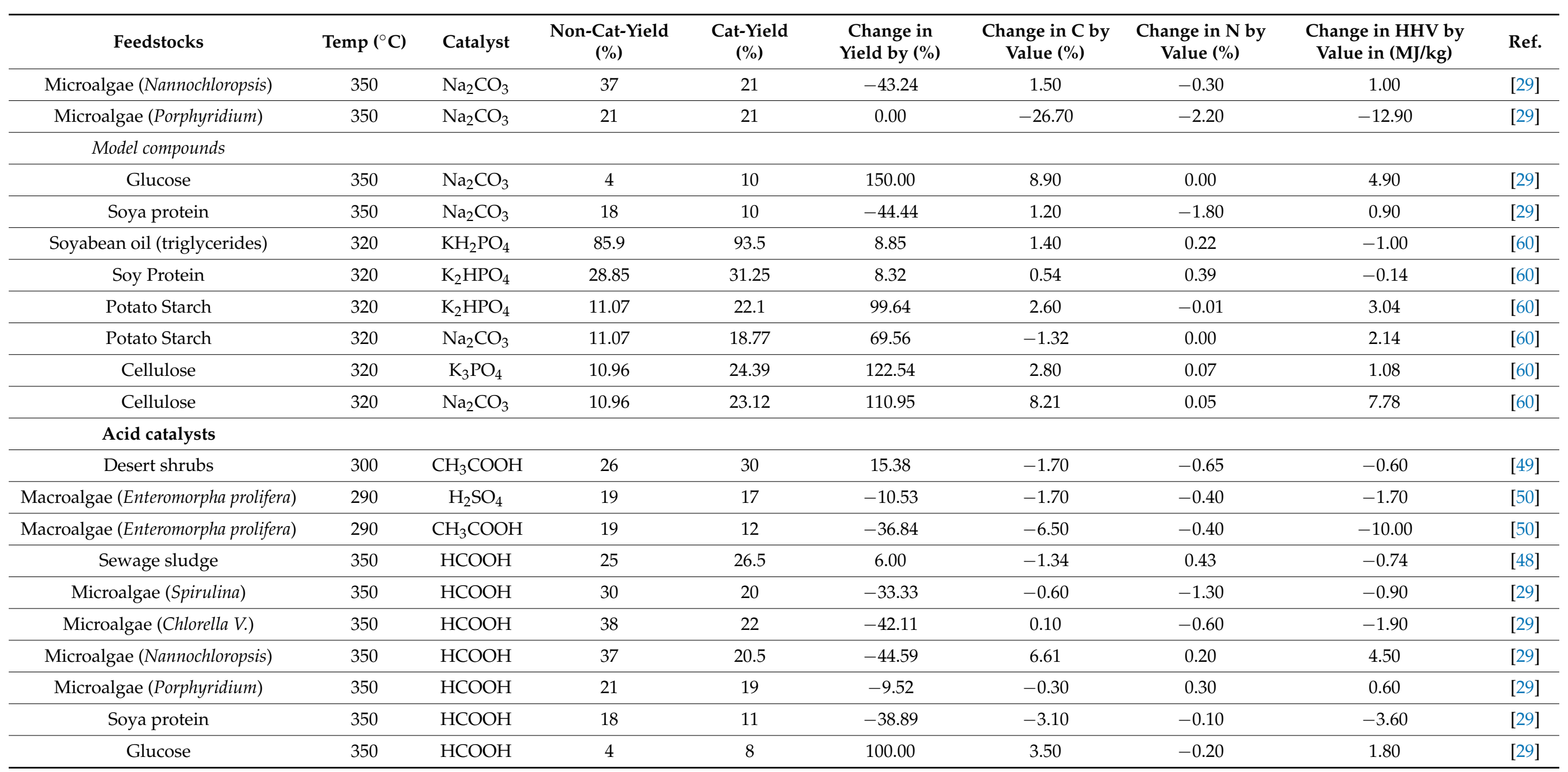


Conti et al. processed cow manure, swine manure, and fish sludge at temperatures of 350 and $400{ }^{\circ} \mathrm{C}$ with potassium salts. The negative effect of the catalyst was noticed on biocrude yield in the range of -4 to $-8 \%$ from all the feedstocks at both temperatures. Nonetheless, catalyst promoted deoxygenation reactions and higher carbon contents were transferred to biocrude at $400{ }^{\circ} \mathrm{C}$ [36]. At supercritical conditions, it was noticed that a higher amount of gase, that resulting in a higher removal of oxygen in the form of $\mathrm{CO}_{2}$. This infers that the release of oxygen with a loss of organic carbon to the gas phase ultimately affects the magnitude of biocrude yield [36].

For high protein-containing feedstocks such as sewage sludge and microalgae, the catalytic effect of the alkalis depends upon the amount of carbohydrates and ash content $[28,48,72,73]$. Sometimes the intrinsic content of ash-alkaline inorganic compounds (carbonates, oxides, etc.) in the feedstock may deactivate the employed catalyst, after becoming dissolved in the water phase [65]. However, this intrinsic ash content may exert a catalytic activity by itself. This was observed by Suzuki et al., who performed the HTL of sewage sludge with the addition of sodium carbonate $\left(\mathrm{Na}_{2} \mathrm{CO}_{3}\right)$ They concluded that the addition of $\mathrm{Na}_{2} \mathrm{CO}_{3}$ could play a positive role in enhancing biocrude yield in the case only a low amount of ash is present in feedstock [22] Indeed, catalyst addition to high ash-containing feedstock was unnecessary, as HTL yields were already high due to the intrinsic inorganic (mostly Ca) content in sewage sludge. On the other hand, Shah et al. [28] reported a positive impact of $\mathrm{K}_{2} \mathrm{CO}_{3}$ on both biocrude yield ( +3 to $+5 \%$ ) and $\mathrm{HHV}$ from high ash-containing (ash: 40\%) sewage sludge with a high fraction of carbohydrates (48\% daf) at 350 and $400{ }^{\circ} \mathrm{C}$. This implies that, irrespective of the intrinsic ash content, the addition of potassium carbonate plays an active role in the conversion of carbohydrates, which improves biocrude productivity. Therefore, the addition of an alkali catalyst is still meaningful when a high amount of carbohydrates is present in the feedstock. However, in the same study [28], lower nitrogen was recorded at $400{ }^{\circ} \mathrm{C}$ in the catalytic run $(-1.43 \%$ by value, compared with nitrogen in the non-catalyzed biocrude). The carbonates generated by the dissolution of $\mathrm{K}_{2} \mathrm{CO}_{3}$ react with ammonium ions derived from amino acids (via deamination) and form ammonium carbonate, which can easily be dissolved in the aqueous phase $[74,75]$. This phenomenon cuts off the reaction pathway for the formation of amides and induces lower nitrogen in catalytic biocrude, as given in Equations (4) and (5) [28].

$$
\begin{gathered}
\mathrm{K}_{2} \mathrm{CO}_{3}+2 \mathrm{NH}_{4}^{+} \rightarrow\left(\mathrm{NH}_{4}\right)_{2} \mathrm{CO}_{3}+2 \mathrm{~K}^{+} \\
\left(\mathrm{NH}_{4}\right)_{2} \mathrm{CO}_{3} \rightarrow \mathrm{NH}_{3}+\mathrm{CO}_{2}+\mathrm{H}_{2} \mathrm{O}
\end{gathered}
$$

Chen et al. utilized a calcium carbonate with high ash containing microalgae, and experienced an inverse relationship between nitrogen content in the biocrude and concentration of calcium carbonate in the feedstock [76]. However, the actual mechanism through which these carbonates react with $\mathrm{N}$-containing compounds within HTL requires further research [77]. Bio-pulp from food waste was processed at 350 and $400{ }^{\circ} \mathrm{C}$ with and without $\mathrm{K}_{2} \mathrm{CO}_{3}$ catalysts. The best performance was achieved at sub-critical conditions (ER: $61.7 \%$ and biocrude yield: $36.6 \%$ ), better than the results obtained at $400{ }^{\circ} \mathrm{C}$. Subsequently, recycling of concentrated organics from the aqueous phase was applied and this enhanced the biocrude yield up to $49.3 \%$ after four recirculation cycles [62].

Aquatic biomasses, especially micro- and macroalgae, have been widely used for a long time as promising candidates for biofuel production [34,37,55,64,78-80]. Generally, low or moderate temperatures $\left(280\right.$ to $350{ }^{\circ} \mathrm{C}$ ) are preferred for the liquefaction of microalgae $[30,42]$. Numerous studies show that alkali catalysts negatively affect the conversion of microalgae by depleting the yield and quality of biocrude. The main factor behind the inefficiency of the alkali catalyst is that as these are incompatible for the cleavage of peptide linkage bonds of protein-containing biomass [29,30,42,81]. Shakya et al. processed microalgae (Pavlova, Isochrysis, and Nannochloropsis) containing variable range of carbohydrate contents in subcritical water. Biocrude yields followed the percentage of carbohydrates (higher to lower) in the feedstock, according to the order: Pavlova > Isochrysis 
$>$ Nannochloropsis [30]. It is reported that the Maillard reaction plays a vital role during the conversion of high protein-containing feedstock, which occurs between the amino acids and polysaccharides [74].

In order to investigate lipid conversion, researchers have often used model compounds. Ding et al. liquefied model compounds, particularly soya bean oil (reference component for triglycerides or lipids), protein, starch, and cellulose with alkali phosphates $\left(\mathrm{KH}_{2} \mathrm{PO}_{4}\right.$, $\mathrm{K}_{2} \mathrm{HPO}_{4}$, and $\left.\mathrm{K}_{3} \mathrm{PO}_{4}\right)$, and alkalis $\left(\mathrm{Na}_{2} \mathrm{CO}_{3}\right.$, and $\left.\mathrm{KOH}\right)$. Biocrude yield was increased more than two times by using $\mathrm{K}_{2} \mathrm{HPO}_{4}$ and $\mathrm{K}_{3} \mathrm{PO}_{4}$ from starch, and cellulose at $320{ }^{\circ} \mathrm{C}$, higher than the $\mathrm{Na}_{2} \mathrm{CO}_{3}$. The HHVs were not enhanced significantly by alkali catalysts [60].

It is a fact that biocrude yield and quality both determine the efficiency of the catalyst. Therefore, the energy recovery must be taken as a decisive value to rate the effectiveness of the catalyst for the biomass conversion. Figure 1 depicts that alkali catalysts increase energy recovery in all lignocellulosic feedstocks, whereas alkali salts along with organic acids show a reverse or negative effect on energy recovery for high protein-containing feedstocks.

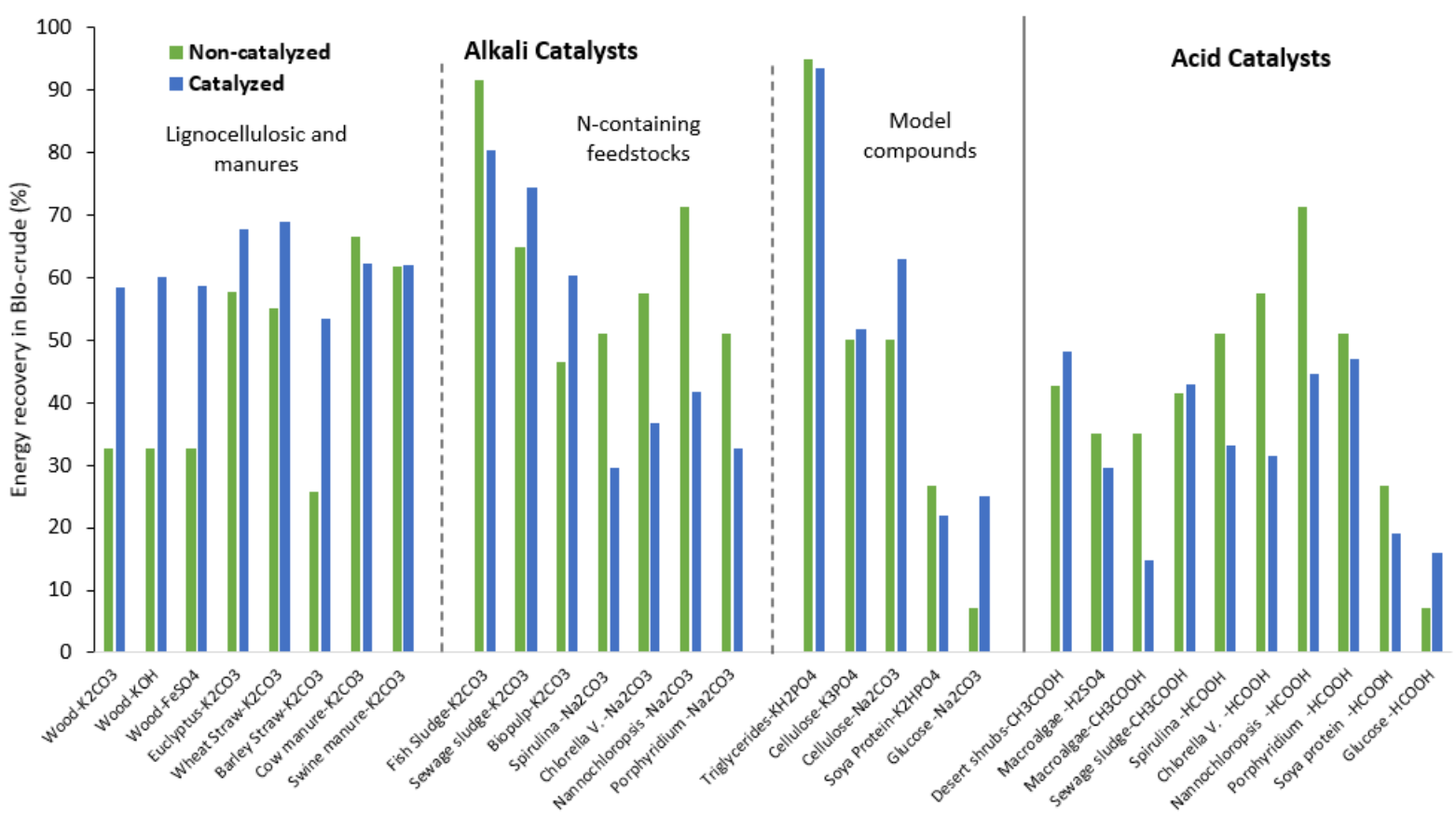

Figure 1. Effect of homogenous catalyst on ER of biocrude from different feedstocks.

\subsection{Acid Catalysts}

Acid catalysts such as formic acid $(\mathrm{HCOOH})$, acetic acid $\left(\mathrm{CH}_{3} \mathrm{COOH}\right)$, hydrochloric acid $(\mathrm{HCl})$, and sulfuric acid $\left(\mathrm{H}_{2} \mathrm{SO}_{4}\right)$ have been employed in many cases of biomass conversion $[29,34,42,50]$. Acid catalysts are not considered as promising as alkali salts, especially for lignocellulosic biomass. For example, biomass (desert shrubs) was treated in an acetic acid medium that increased the biocrude yield from 26 to $30 \%$ with no effect on calorific values [49]. Yin et al. [70] presented an interesting study on cellulose under acidic, neutral, and alkaline conditions by developing variable $\mathrm{pH}$ values of 3,7 , and 14 from $\mathrm{HCl}$, water, and $\mathrm{NaOH}$, respectively, at temperatures of $275-320^{\circ} \mathrm{C}$. The reaction mechanism of the conversion of cellulose was different according to the $\mathrm{pH}$ of the solution. $\mathrm{NaOH}$ directed the conversion process towards the formation of $\mathrm{C}_{2-5}$ carboxylic acids. In contrast, 5-HMF was found to be the most dominant compound in acidic conditions, which tends to polymerize and resulted in higher char formation. Neutral conditions showed both 5-HMF and carboxylic acids due to the self-dissociation of $\mathrm{H}_{2} \mathrm{O}$ to $\mathrm{H}^{+}$and $\mathrm{OH}^{-}$at high temperatures. The conversion pathways of cellulose under different conditions are illustrated in Figure 2. 


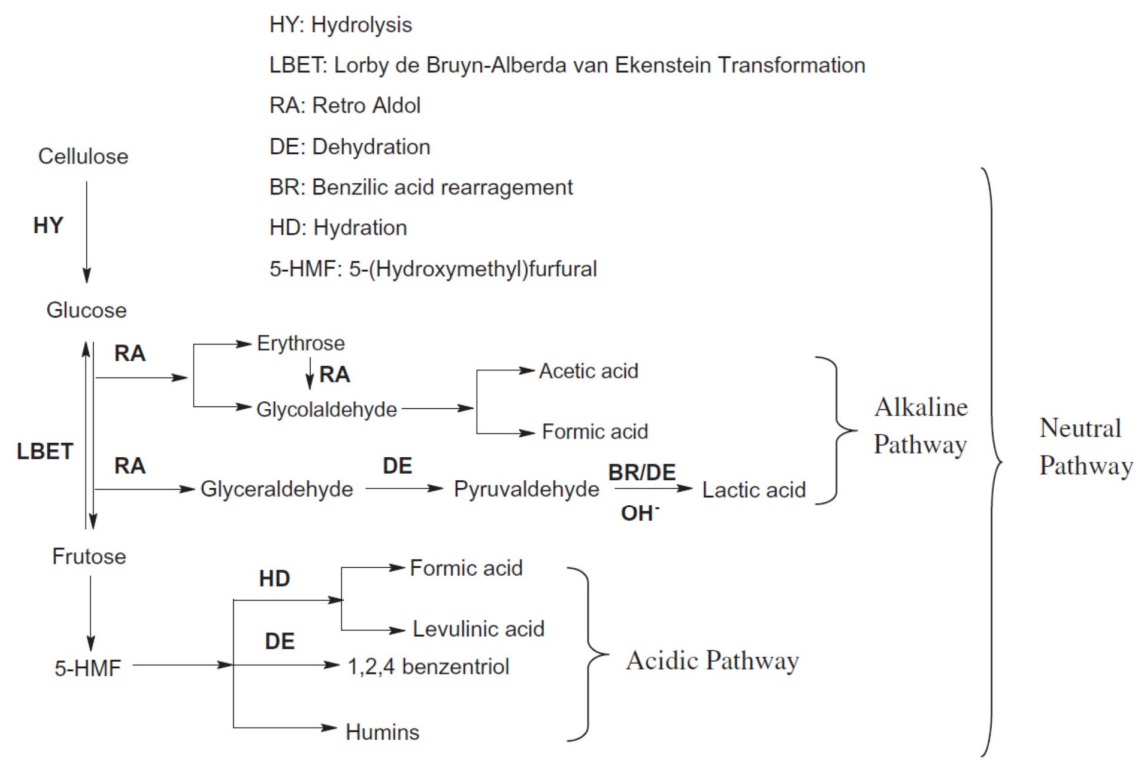

Figure 2. The decomposition of the cellulose under acidic, neutral, and alkaline conditions. Reproduced from [70] with permission from Elsevier (Amsterdam, The Netherlands), (c Elsevier 2012.

Yang et al. investigated the effect of acid catalysts $\left(\mathrm{H}_{2} \mathrm{SO}_{4}\right.$ and $\left.\mathrm{CH}_{3} \mathrm{COOH}\right)$ on macroalgae (Enteromorpha prolifera) and observed negative impacts on biocrude.. However, acid catalysts considerably increased the concentration of ketones in biocrudes [50]. Similarly, Shah et al. reported the insignificant effect of acetic acid on biocrude yield and energy recovery from sewage sludge, also finding that a slightly lower amount of carbon was transferred to the biocrude compared to non-catalytic samples [50].

Biller et al. performed a comprehensive catalytic study by using catalysts $\mathrm{CH}_{3} \mathrm{COOH}$ and $\mathrm{HCOOH}$ on microalgae (high protein-containing Spirulina and high lipid-containing Chlorella) and compared those with alkali catalysts $\left(\mathrm{KOH}\right.$ and $\left.\mathrm{Na}_{2} \mathrm{CO}_{3}\right)$. The results revealed that both acids improved the biocrude yield, with a slightly higher amount of gases. During $\mathrm{HTL}$, the added acids were found to be consumed, suggesting their behavior more as reactants than as catalysts. Improved biocrude HHVs were determined with alkali catalysts with a difference of 2 to $3 \mathrm{MJ} / \mathrm{kg}$ compared to acid catalysts [42]. In another study, the same authors explored the catalytic action of formic acid and alkali carbonate on glucose and soya protein. For soya protein, the negative effect of formic acid was noticed on energy recovery, while greater energy recoveries were obtained from glucose under both alkali and formic acid mediums [29]. It was also mentioned by Kruse et al. that lower production of N-heterocyclic compounds in the biocrude, occurring in an acidic environment, resulted in the production of higher amount of char [82].

Hu et al. [83] treated microalgae (Chlorella vulgaris) under acidic and alkaline conditions with $\mathrm{HCOOH}$ and $\mathrm{Na}_{2} \mathrm{CO}_{3}$ at $275^{\circ} \mathrm{C}$ for 50 mins. The biocrude yield obtained from $\mathrm{Na}_{2} \mathrm{CO}_{3}$ $(11 \%)$ was lower than the non-catalyzed conditions, while $\mathrm{HCOOH}$ led to almost the same biocrude yield from HTL (29\%). Aqueous phase recycling with alkali salt improved the biocrude yield to a larger extent. The activation of $\mathrm{Na}_{2} \mathrm{CO}_{3}$ with aqueous phase recycling might be occurred due to a decrease in solubility of the organic compounds due to the "salting out" effect, which drives them into the biocrude stream, thus contributing to an increase in biocrude yields.

\subsection{Further Studies on Homogenous Catalysts}

A number of HTL studies concerning homogenous catalysts are present in the literature, some of which could not be included in the discussion. In Table 2, the major findings from some recently published catalytic HTL studies are listed, in order to provide a more complete picture of the state-of-the-art. 
Table 2. Major findings from HTL studies using homogenous catalysts.

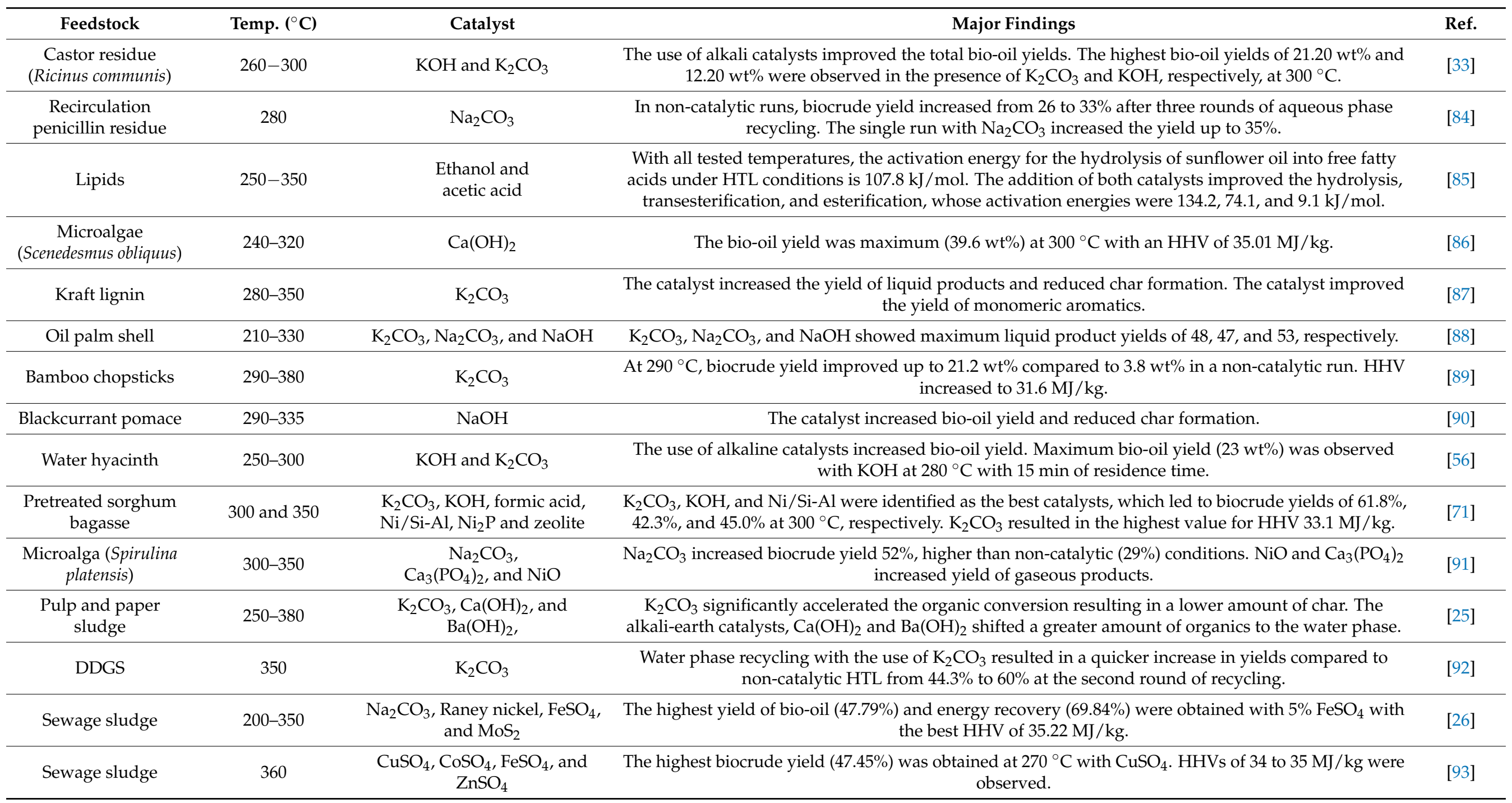




\section{Heterogeneous Catalysts}

Heterogeneous catalysts for the catalytic thermochemical conversion of different biomass have been used widely due to their unique advantages such as high catalytic activity, selectivity, recyclability, and reusability over homogeneous catalysts. Furthermore, properties such as tunable structure, shape selectivity, and sustained nature of heterogeneous catalysts are important considerations for their employability in industrial-scale biomass conversion processes. The development of high-performance heterogeneous catalysts with substantial amounts of catalytic active sites is important in achieving higher reaction rates, especially in cascade biomass conversion processes. A few reports have discussed the role of heterogeneous catalysts in the improvement of yield and the properties of biocrude obtained through the HTL of different biomass.

Among the different types of heterogeneous catalysts, three broad categories such as redox metals or acidic metal oxides (e.g., $\mathrm{CeO}_{2}, \mathrm{ZrO}_{2}$, Fe and $\mathrm{Cu}$ based), noble metals (e.g., $\mathrm{Pd}, \mathrm{Pt}$, Ru based), and non-noble metals (e.g., all other transition metals) have been used widely for the catalytic HTL of different biomass. Among the above-mentioned categories, catalysts based on redox metals possess unique abilities for easy regeneration due to their fast oxidation-reduction kinetics. Furthermore, these catalysts are suggested to promote the formation and hydrogenation of light organic compounds in the water-soluble fraction [94]. On the other hand, noble metal-based catalysts possess high catalytic activity toward the reduction in a wide range of oxygen-containing compounds to hydrocarbons present in the varieties of biomass [95]; whereas the heterogeneous catalysts containing base transition metals have been proven to be proficient in improving the quality of the bio-oil through the deoxygenation and denitrification of biomass containing oxygen and nitrogen compounds [52]. The main categories of biomass studied for the catalytic HTL are lignocellulosics, algae as well as lipid and protein-containing feedstocks such as sewage sludge and food waste. The nature of biomass feedstock also influences the catalytic action of heterogeneous catalysts, thus overall, affects the bio-oil yield and quality due to different biomass compositions. Almost all biomass materials include inorganic nutrients present in the form of precipitates or salts of carboxylic and/or phenolic groups, which may accumulate on the catalyst surface and affect catalytic activity [96]. Different categories of heterogeneous catalysts used previously for the catalytic HTL of different biomass are listed in Table 3 and discussed in detail in the following sections. 
Table 3. Effects of heterogeneous catalysts on biocrude yield, carbon, and HHVs.

\begin{tabular}{|c|c|c|c|c|c|c|c|c|c|}
\hline Feedstocks & $\begin{array}{l}\text { Temp } \\
\left({ }^{\circ} \mathrm{C}\right)\end{array}$ & Catalyst & $\begin{array}{c}\text { Non-Cat-Yield } \\
(\%)\end{array}$ & $\begin{array}{l}\text { Cat-Yield } \\
(\%)\end{array}$ & $\begin{array}{l}\text { Change in } \\
\text { Yield by (\%) }\end{array}$ & $\begin{array}{c}\text { Change in } C \text { by } \\
\text { Value }(\%)\end{array}$ & $\begin{array}{c}\text { Change in } \mathrm{N} \text { by } \\
\text { Value }(\%)\end{array}$ & $\begin{array}{l}\text { Change in } \mathrm{HHV} \\
\text { by Value (MJ/kg) }\end{array}$ & Ref. \\
\hline \multicolumn{10}{|l|}{ Redox metals } \\
\hline Wood (birchwood sawdust) & 300 & $\mathrm{MgO}$ & 19.00 & 30.00 & 57.89 & -5.00 & 0.03 & -2.00 & [32] \\
\hline Macroalgae (Ulva prolifera) & 280 & $\mathrm{MgO}$ & 17.00 & 16.00 & -5.88 & 13.00 & -0.40 & -2.80 & [97] \\
\hline Macroalgae (Ulva prolifera) & 280 & $\mathrm{Al}_{2} \mathrm{O}_{3}$ & 17.00 & 26.00 & 52.94 & 10.00 & -0.70 & -3.40 & [97]) \\
\hline Macroalgae (Ulva prolifera) & 280 & $\mathrm{MgCl}_{2}$ & 17.00 & 27.00 & 58.82 & 11.00 & -0.20 & 0.60 & [97] \\
\hline Human feces & 330 & $\mathrm{Ni}-\mathrm{Tm} / \mathrm{TiO}_{2}$ & 40.00 & 44.00 & 10.00 & -4.87 & 1.18 & -4.78 & [99] \\
\hline Human feces & 330 & $\mathrm{Tm} / \mathrm{TiO}_{2}$ & 40.00 & 40.00 & 0.00 & -2.61 & 0.47 & -2.78 & [99] \\
\hline Human feces & 330 & $\mathrm{Ni} / \mathrm{TiO}_{2}$ & 40.00 & 41.00 & 2.50 & -3.83 & 0.64 & -2.78 & [99] \\
\hline Human feces & 330 & $\mathrm{TiO}_{2}$ & 40.00 & 40.00 & 0.00 & 0.79 & 0.79 & -0.78 & [99] \\
\hline \multicolumn{10}{|l|}{ Noble metals } \\
\hline Microalgae (Nannochloropsis sp.) & 350 & $\mathrm{Pd} / \mathrm{C}$ & 35.00 & 57.00 & 62.86 & -2.00 & -0.38 & 0.00 & [95] \\
\hline Microalgae (Nannochloropsis sp.) & 350 & $\mathrm{Ru} / \mathrm{C}$ & 35.00 & 50.00 & 42.86 & -3.00 & -0.69 & -1.00 & [95] \\
\hline \multicolumn{10}{|l|}{ Non-noble metals } \\
\hline Oak wood & 330 & Nickel powder & 33.00 & 35.00 & 6.06 & -1.00 & 0.00 & 0.31 & [100] \\
\hline Oak wood & 330 & $\begin{array}{c}\text { Nano-spiked } \\
\text { Nickel }\end{array}$ & 33.00 & 37.00 & 12.12 & -0.50 & 0.00 & 0.94 & [100] \\
\hline Rice husk & 300 & $\mathrm{La}_{2} \mathrm{O}_{3}$ & 23.80 & 32.50 & 36.55 & 9.94 & -0.31 & 5.66 & [101] \\
\hline Rice husk & 301 & $\mathrm{Dy}_{2} \mathrm{O}_{3}$ & 23.80 & 31.20 & 31.09 & 5.95 & -0.12 & 3.12 & [101] \\
\hline Microalgae (Nannochloropsis sp.) & 350 & Zeolite & 35.00 & 45.00 & 28.57 & 2.00 & 0.15 & -3.00 & [95] \\
\hline Microalgae (Spirulina) & 290 & $\mathrm{Ni} / \mathrm{CNT}$ & 28.00 & 32.00 & 14.29 & 5.40 & -0.40 & 8.00 & [98] \\
\hline $\begin{array}{l}\text { Microalgae } \\
\text { (Spirulina) }\end{array}$ & 290 & $\mathrm{Co} / \mathrm{CNT}$ & 28.00 & 41.00 & 46.43 & 13.10 & -1.10 & 12.40 & [98] \\
\hline
\end{tabular}


Table 3. Cont.

\begin{tabular}{|c|c|c|c|c|c|c|c|c|c|}
\hline Feedstocks & $\begin{array}{l}\text { Temp } \\
\left({ }^{\circ} \mathrm{C}\right)\end{array}$ & Catalyst & $\begin{array}{c}\text { Non-Cat-Yield } \\
(\%)\end{array}$ & $\begin{array}{l}\text { Cat-Yield } \\
(\%)\end{array}$ & $\begin{array}{l}\text { Change in } \\
\text { Yield by (\%) }\end{array}$ & $\begin{array}{c}\text { Change in } \mathrm{C} \text { by } \\
\text { Value }(\%)\end{array}$ & $\begin{array}{c}\text { Change in } \mathrm{N} \text { by } \\
\text { Value }(\%)\end{array}$ & $\begin{array}{c}\text { Change in HHV } \\
\text { by Value (MJ/kg) }\end{array}$ & Ref. \\
\hline $\begin{array}{c}\text { Microalgae } \\
\text { (Chlorella vulgaris) }\end{array}$ & 300 & $\mathrm{NiMo} / \mathrm{Al}_{2} \mathrm{O}_{3}$ & 32.00 & 29.00 & -9.38 & 10.77 & 3.52 & 4.10 & [51] \\
\hline $\begin{array}{c}\text { Microalgae } \\
\text { (Chlorella vulgaris) }\end{array}$ & 300 & $\mathrm{CoMo} / \mathrm{Al}_{2} \mathrm{O}_{3}$ & 32.00 & 35.00 & 9.38 & 12.19 & 3.49 & 4.97 & [51] \\
\hline Sewage sludge & 300 & $\mathrm{NiMo} / \mathrm{Al}_{2} \mathrm{O}_{3}$ & 27.00 & 24.00 & -11.11 & 4.00 & 0.03 & 2.42 & [51] \\
\hline Sewage sludge & 300 & $\mathrm{CoMo} / \mathrm{Al}_{2} \mathrm{O}_{3}$ & 27.00 & 21.00 & -22.22 & 1.00 & 2.29 & 0.42 & [51] \\
\hline \multicolumn{10}{|l|}{ Other heterogeneous catalysts } \\
\hline Wood (birchwood sawdust) & 300 & $\begin{array}{l}\text { hydrotalcite } \\
\text { (HT) }\end{array}$ & 19.00 & 34.00 & 78.95 & -7.00 & 0.00 & -5.00 & [32] \\
\hline Wood (birchwood sawdust) & 300 & Colemanite & 19.00 & 36.00 & 89.47 & -3.00 & 0.00 & -2.00 & [32] \\
\hline Wood (birchwood sawdust) & 300 & $\mathrm{HT} / \mathrm{KOH}$ & 19.00 & 36.00 & 89.47 & -6.00 & 0.02 & 1.00 & [32] \\
\hline $\begin{array}{c}\text { Microalgae } \\
\text { (Chlorella vulgaris) }\end{array}$ & 300 & activated carbon & 32.00 & 26.00 & -18.75 & 15.66 & 4.50 & 10.34 & [51] \\
\hline
\end{tabular}




\subsection{Redox Catalysts}

Redox catalysis involves the most fundamental chemical reactions and transformations in which the catalyst undergoes both oxidation and reduction reactions (i.e., loss and gain of electrons), resulting in a change in its oxidation state. Among the vast majority of redox catalysts, the oxides and salts of redox-active transition metals such as iron (Fe), copper $(\mathrm{Cu})$, zirconium $(\mathrm{Zr})$, titanium $(\mathrm{Ti})$, magnesium $(\mathrm{Mg})$, and a few lanthanides (e.g., La and Ce) have been used repeatedly for the catalytic HTL of different biomass due to their redox-active catalytic sites, easy regeneration as well as high activity and selectivity.

Redox catalysts, especially Fe-based, have an affinity for producing in situ hydrogen and for the subsequent hydrogenation of reactive chemical species when used in aqueous media (i.e., water) [102]. Previously, the effect of the addition of $10 \%$ iron in different oxidation states $\left(\mathrm{Fe}, \mathrm{Fe}_{3} \mathrm{O}_{4}\right.$, and $\left.\mathrm{Fe}_{2} \mathrm{O}_{3}\right)$ as redox catalysts was observed in the HTL of oak wood at different temperatures in a range of $260-320^{\circ} \mathrm{C}$ [64]. The increment in HTL biocrude yields was about $30 \%$ and $13 \%$ with $\mathrm{Fe}$ and $\mathrm{Fe}_{3} \mathrm{O}_{4}$ catalysts, respectively, in comparison to that obtained without catalysts. However, no effect of the $\mathrm{Fe}_{2} \mathrm{O}_{3}$ catalyst on the bio-oil yield was observed. Furthermore, the enhanced $\mathrm{H} / \mathrm{C}$ ratio of bio-oil of about $15 \%$ with respect to the non-catalytic HTL run indicated the hydrogenation of organic compounds in biomass with in situ generated hydrogen from water through the oxidation of $\mathrm{Fe}$ to $\mathrm{Fe}_{3} \mathrm{O}_{4}$.

In another report, $\mathrm{Fe}(0)$ was used as a redox agent for in situ hydrogen generation in catalytic HTL of lignocellulosic palm oil fruit bunch, producing bio-oil containing higher yields of water-soluble and water-insoluble fractions [103]. Upon increasing the $\mathrm{H}_{2} \mathrm{O}$ /biomass ratio from 0:1 to 5:1 in the presence of Fe, the HTL bio-oil yield was significantly enhanced from $25 \%$ to $79 \%$, whereas the yield of solid residue was decreased. A similar trend in the yield of gaseous products was observed upon the addition of Fe catalyst. After completion of the HTL test, the oxidized catalyst mixed with char was regenerated by heating $1000{ }^{\circ} \mathrm{C}$ at a rate of $10{ }^{\circ} \mathrm{C} / \mathrm{min}$ under a $\mathrm{N}_{2}(100 \mathrm{~mL} / \mathrm{min})$ atmosphere for $2 \mathrm{~h}$. The resulting reduced zerovalent Fe catalyst was reused in the HTL experiment of the palm oil fruit bunch.

Recently, Xu et al. explored the role of metallic Fe (10 wt\%) in the production of in situ hydrogen during the catalytic HTL of cornstalk biomass through the controlled experiments carried out with $\mathrm{Fe}_{3} \mathrm{O}_{4}$ [104]. HTL of cornstalk biomass was conducted in ethanol-water solvent mixture $(50 / 50,30 \mathrm{v} / \mathrm{v})$ at $300{ }^{\circ} \mathrm{C}$ for $30 \mathrm{~min}$ in a $100 \mathrm{~mL}$ autoclave reactor. Fe led to the hydrogenation and deoxygenation of oxygenates present in biomass, consequently, improvement in the biocrude yield and quality in terms of higher $\mathrm{H} / \mathrm{C}$ and $\mathrm{HHV}$ was noticed. However, the $\mathrm{Fe}_{3} \mathrm{O}_{4}$ showed a negligible catalytic effect in the HTL process.

The role of the heterogeneous $\mathrm{CeZrO}_{x}$ catalyst containing the redox Ce metal for promoting the in situ deoxygenation of water-soluble compounds to oil-soluble hydrocarbon products during catalytic HTL of food waste was investigated [105]. It was found that liquefaction of food waste at $300^{\circ} \mathrm{C}$ for $1 \mathrm{~h}$ in the presence of the $\mathrm{CeZrO}_{\mathrm{x}}$ catalyst improved both biocrude $\mathrm{HHV}$ and energy recovery compared to non-catalytic experiments. Comparatively, the HTL aqueous phase and biocrude obtained in the presence of $\mathrm{CeZrO}_{x}$ contained around half of the total organic carbon and less water-soluble organics, respectively. The catalyst was sustained after approximately $16 \mathrm{~h}$ of hydrothermal processing of food waste at $300{ }^{\circ} \mathrm{C}$, which was reused three times for the conversion of model compounds.

The effect of a monoclinic $\mathrm{ZrO}_{2}$ catalyst on the yield and properties of HTL biocrude obtained from dried distiller grains with solubles (DDGS) at a temperature of $300{ }^{\circ} \mathrm{C}, 250$ bar pressure, and $15 \mathrm{~min}$ in a stop-flow reactor was investigated [106]. The detailed investigation of biocrude yield and its characteristic properties such as ash content, elemental composition, heating value, and chemical composition revealed the poor catalytic activity of $\mathrm{ZrO}_{2}$ for the HTL of biomass.

Zhang et al. investigated the role of $\mathrm{Ni}-\mathrm{Tm} / \mathrm{TiO}_{2}$ catalysts for the removal of heteroatoms and saw an increase in biocrude yield in the HTL of human feces [99]. The yield of HTL biocrude, obtained at a temperature of $330{ }^{\circ} \mathrm{C}$ and a reaction time of $30 \mathrm{~min}$, 
increased from $41.57 \%$ to $46.09 \%$ upon the addition of the $\mathrm{Ni}-\mathrm{Tm} / \mathrm{TiO}_{2}$ catalyst. Furthermore, the high conversion rate of human feces $(89.61 \%)$ and high-energy recovery of the resulting biocrude $(87.42 \%)$ showed the potential of $\mathrm{Ni}-\mathrm{Tm} / \mathrm{TiO}_{2}$ for the catalytic $\mathrm{HTL}$ of high heteroatoms containing biomass. The synergistic effect of $\mathrm{Ni}$ led to superior catalytic activity of the $\mathrm{Ni}-\mathrm{Tm} / \mathrm{TiO}_{2}$ catalyst for the desulfurization of biocrude and resulted in $22.58 \%$ reduction in sulfur contents.

Catalytic HTL of microalga Ulva prolifera was carried out over various metal oxides such as $\mathrm{MgO}, \mathrm{CaO}, \mathrm{Al}_{2} \mathrm{O}_{3}, \mathrm{ZrO}_{2}$, and $\mathrm{CeO}_{2}$ and metal salts $\left(\mathrm{MgCl}_{2}, \mathrm{FeCl}_{3}\right.$, and $\left.\mathrm{CuCl}_{2}\right)$ as catalysts at different operating temperatures $\left(260,280\right.$, and $\left.300^{\circ} \mathrm{C}\right)$ using water, methanol, and ethanol as solvents [97]. Among the above-mentioned metal oxides, the highest biocrude yield of $50.6 \mathrm{wt} \%$ containing a higher amount of ester groups was achieved using the $\mathrm{MgO}$ catalyst in ethanol solvent. The regeneration of the $\mathrm{MgO}$ catalyst was carried out by treating the recovered spent catalyst from the bio-char at $550{ }^{\circ} \mathrm{C}$ for $3 \mathrm{~h}$ under an oxygen atmosphere, which was then reused three times in the liquefaction reaction with macroalgae under both ethanol and water solvents. This study verifies the high reproduction ability of the $\mathrm{MgO}$ catalyst for the HTL of macroalgae.

\subsection{Noble Metal Catalysts}

Noble metals are considered as highly valuable metals because of their low abundance and high corrosion resistant properties. Noble metal catalysts have been found to be effective in the key catalytic reaction steps such as hydrogenation, hydrodeoxygenation, dehydration, and oxidation for the formation of high-value products from different biomass [107]. Previously, a heterogeneous $\mathrm{Pd}-\mathrm{Ir}-\mathrm{ReO}_{x} / \mathrm{SiO}_{2}$ catalyst containing $\mathrm{ReO}_{x}$ deposited on noble Pd and Ir metal particles was used for the catalytic hydrogenation of furfural, a main derivative of hexose and pentose sugars present in lignocellulosic biomass, to 1,5-pentanediol. Figure 3 shows the mechanistic pathway for the hydrogenation of the furfural formation of hydride species over the $\mathrm{Pd}-\mathrm{Ir}-\mathrm{ReO} \mathrm{O}_{\mathrm{x}} / \mathrm{SiO}_{2}$ catalyst. The $\mathrm{ReO}$ species with modified Pd and Ir sites decreased the metal particle size and increased dispersion of Pd and Ir metals, therefore enhancing the catalytic activity for the hydrogenation of furfural into 1,5-pentanediol.

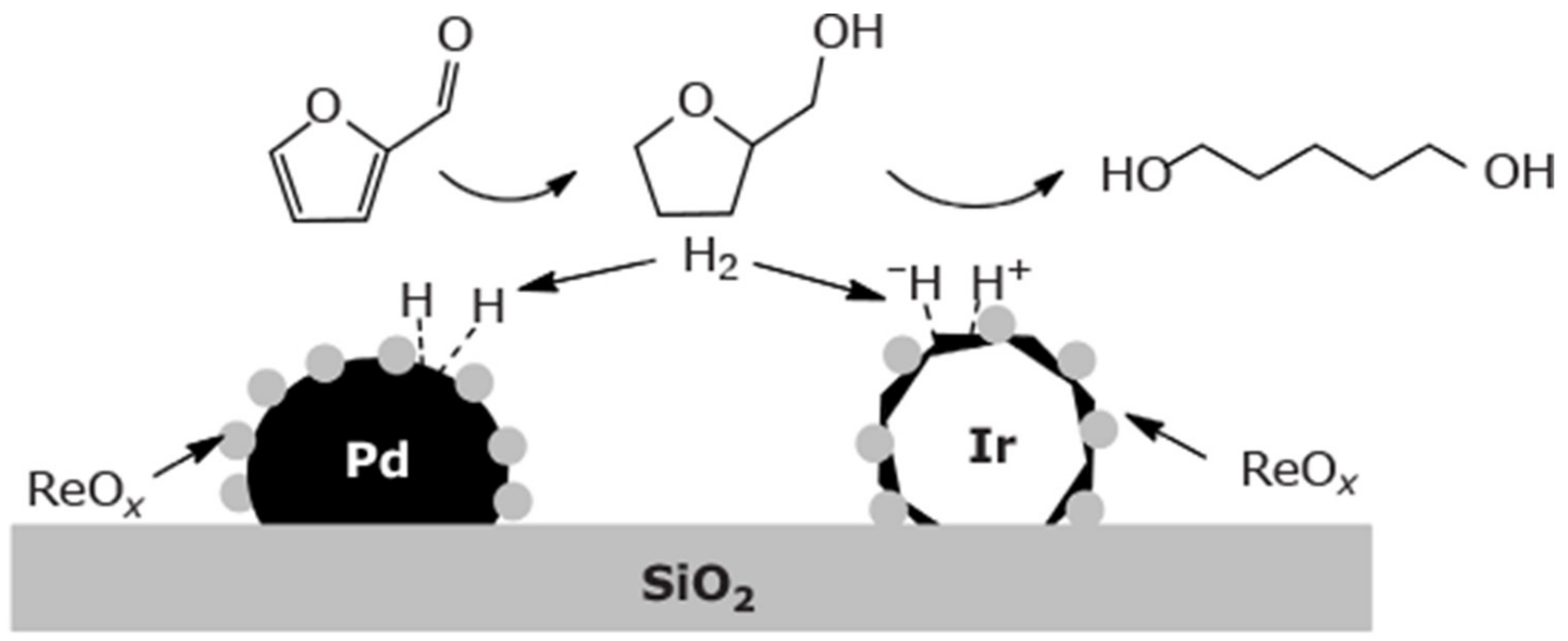

Figure 3. Mechanism of the catalytic action of $\mathrm{Pd}-\mathrm{Ir}-\mathrm{ReO}_{\mathrm{x}} / \mathrm{SiO}_{2}$ for the conversion of furfural to 1,5pentanediol. Republished with permission of the Royal Society of Chemistry from [108]. Permission conveyed through Copyright Clearance Center, Inc. (Senai, Malaysia). 
Despite the high cost of noble metal-based catalysts, a few reports exist that have critically assessed and summarized the contribution of noble metal catalysts for catalytic HTL of cellulosic, microalgae, and soy protein-based biomass feedstocks. Noble metalbased catalysts mainly encounter problems of limited reserve and poor stability; therefore, support materials in heterogeneous catalysis are critical for the stability and efficiency of these catalysts [109]. Duan et al. used a variety of carbon-supported noble metal-based heterogeneous catalysts such as $\mathrm{Pt} / \mathrm{C}, \mathrm{Pd} / \mathrm{C}$, and $\mathrm{Ru} / \mathrm{C}$ for the catalytic HTL of Nannochloropsis sp. microalga at $350{ }^{\circ} \mathrm{C}$ temperature in the absence and presence of $\mathrm{H}_{2}$ [95]. The above-supported catalysts were selected due to their abilities for reduction, hydrogenation, and deoxygenation of heteroatom (e.g., $\mathrm{S}, \mathrm{O}$, and $\mathrm{N}$ ) containing compounds. Normally, HTL bio-oil produced from microalgae is an enormously complex mixture of organic compounds with different functional groups and typically contains about $30-40 \%$ of light oil and $60-70 \%$ of heavy asphaltene-based constituents [110]. It was observed that all the catalysts resulted in higher HTL biocrude yields, but none of them had any influence on the HHV and elemental composition of the biocrude in the absence of $\mathrm{H}_{2}$. Carbon-supported Ru catalyst formed a higher amount of methane gas during the catalytic HTL process. Interestingly, the yield of gaseous products was decreased by applying an initial $\mathrm{H}_{2}$ pressure or, in general, by running the system at higher pressures.

Catalytic HTL of a model protein (i.e., soy protein) was carried out using noble metals-based catalysts such as $\mathrm{Pd}, \mathrm{Pt}$, and $\mathrm{Ru}$ supported on porous carbon and $\mathrm{Al}_{2} \mathrm{O}_{3}$ support $[99,111]$. The ideal conditions for the catalytic HTL of soy protein in the presence of $\mathrm{Ru} / \mathrm{C}$ catalyst were found to be for $2 \mathrm{~h}$ retention time at a temperature of $350{ }^{\circ} \mathrm{C}$ with a $50 \mathrm{wt} \%$ loading of the catalyst. However, none of the catalysts had any significant influence on the biocrude yield, although $\mathrm{Ru} / \mathrm{C}(50 \mathrm{wt} \%)$ led to less than half of the heteroatom content (including sulfur and nitrogen) of the biocrude and a 16\% increase in higher heating value in comparison to the heating value of biocrude obtained in the non-catalytic test.

A metal co-catalyst system results in the synergistic acceleration of the catalytic activity of the main catalyst and lowers the activation energy of a chemical reaction by promoting charge separation [112]. Hirano et al. used Fe metal as a co-catalyst to accelerate the catalytic activity of noble metal-based $\mathrm{Pd} / \mathrm{Al}_{2} \mathrm{O}_{3}, \mathrm{Pt} / \mathrm{Al}_{2} \mathrm{O}_{3}$, and $\mathrm{Ru} / \mathrm{Al}_{2} \mathrm{O}_{3}$ catalysts for the selective hydrogenation of oxygenates during the catalytic HTL of lignocellulosic feedstock [94]. In comparison to the Fe-assisted catalytic HTL of cellulose, the presence of the $\mathrm{Fe}$ and $\mathrm{Pd} / \mathrm{Al}_{2} \mathrm{O}_{3}$ catalyst led to an approximately $8-9 \%$ increase in yield of a watersoluble organic fraction under the same conditions. Comparatively, a lower $\mathrm{O} / \mathrm{C}$ ratio and a higher effective $\mathrm{H} / \mathrm{C}$ ratio $\left(\mathrm{H} / \mathrm{C}_{\text {eff }}=1.33\right)$ of the bio-oil obtained in the presence of $\mathrm{Fe}$ and $\mathrm{Pd} / \mathrm{Al}_{2} \mathrm{O}_{3}$ catalyst were achieved than that obtained during Fe-assisted HTL. The enhanced deoxygenation of oxygen-containing compounds present in cellulose was attributed to the synergistic acceleration of the catalytic activity of the $\mathrm{Pd} / \mathrm{Al}_{2} \mathrm{O}_{3}$ catalyst by metallic Fe. It was confirmed that in situ generated $\mathrm{H}_{2}$ by Fe from water under hydrothermal conditions decreased the reducing capacity of Fe in the case of Fe-assisted HTL. Therefore, no effect on the yield of HTL bio-oil was observed. The added noble metal catalyst activates gaseous $\mathrm{H}_{2}$ to form hydrogenated compounds in the water-soluble organic fraction, which would not be possible with only $\mathrm{Fe}$ as a catalyst. However, the efficiency of the catalytic system needs to be improved for biomass HTL to be economically feasible and a plausible HTL mechanism entails to be elucidated. Figure 4 shows a possible mechanism explaining the catalytic action of hydrogenation catalysts on the production of different HTL products [94]. 


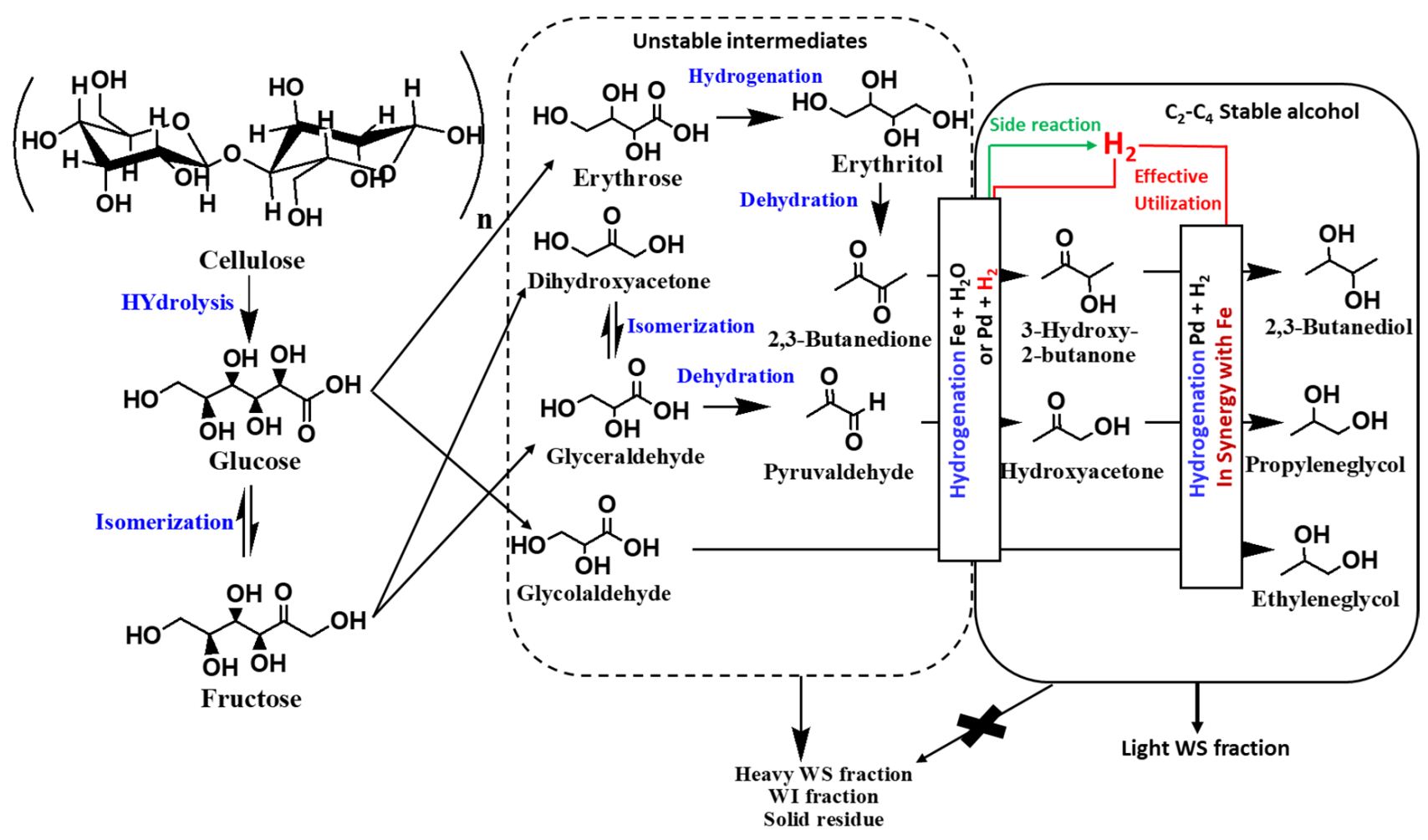

Figure 4. Plausible mechanism for the effect of Pd catalysts on the Fe-assisted HTL of cellulose. Reproduced from [94] with permission from Elsevier (Amsterdam, The Netherlands), (c Elsevier 2020.

\subsection{Non-Noble Metal Catalysts}

Apart from noble metal-based catalysts, the usage of non-noble metal catalysts in catalytic HTL has attracted significant research interest due to their high catalytic activity in bond cleavage, easy recovery, and low cost. Among the non-noble metals, nickel, cobalt, and molybdenum proved to be active in deoxygenation and denitrogenation $[12,64]$.

Recently, the effect of carbon nanotube-supported transition metals such as Co and $\mathrm{Ni}$ was evaluated for the catalytic HTL of Spirulina microalgae in the presence of water, methanol, and ethanol solvents [98]. Among all the catalysts, Co/CNT led to a significant enhancement of $13 \mathrm{wt} \%$ in the biocrude yield in comparison to the non-catalytic test. The highest biocrude yield was found to be $43.6 \%$ with Co/CNT catalysts whereas the minimum yield in the non-catalytic test was $26.8 \mathrm{wt} \%$. The significant enhancement in microalgae conversion and resulting biocrude yield was due to the formation of hydrogen radicals influenced by the Co/CNT catalyst. It was observed that Co/CNT participated in the reaction mechanism and led to the selective production of heptadecane over other catalysts. However, the gas yield was higher $(27.3 \mathrm{wt} \%)$ in the case of $\mathrm{Ni} / \mathrm{CNT}$ than that observed in the presence of Co/CNT.

Catalytic HTL of sewage sludge and Chlorella Vulgaris was carried out at $325^{\circ} \mathrm{C}$ for a $30 \mathrm{~min}$ holding time to demonstrate the influence of $\mathrm{NiMo} / \mathrm{Al}_{2} \mathrm{O}_{3}$ and $\mathrm{CoMo} / \mathrm{Al}_{2} \mathrm{O}_{3}$ catalysts on the yield and quality of biocrude [51]. However, both catalysts did not show any effect on the biocrude yield but showed high catalytic activity to enhance its quality significantly. The $\mathrm{O} / \mathrm{C}$ molar ratio of biocrude was decreased from 0.42 in the non-catalytic run to 0.21 and 0.19 in the presence of CoMo and NiMo based catalysts, respectively, whereas the biocrude yield was decreased by 3\% with NiMo and increased by 3\% with CoMo. The decrease in biocrude yield in the case of NiMo compared to the non-catalytic test was probably due to the formation of light water-soluble compounds. Quantitative desulfurization and lower oxygen contents in HTL biocrude produced from C. vulgaris using NiMo and CoMo catalysts were observed, whereas both catalysts were also active in decreasing the $\mathrm{O} / \mathrm{C}$ and $\mathrm{S} / \mathrm{C}$ ratio of biocrude obtained from sewage sludge. Catalytic HTL 
of oak wood was carried out using commercial Ni powder and nanostructured Ni particles at different temperatures $\left(280-330^{\circ} \mathrm{C}\right)$, reaction times (10-30 $\left.\mathrm{min}\right)$, and catalyst loadings $(10-50 \mathrm{wt} \%)$, in order to enhance the yield and quality of the biocrude [100]. Flower-like morphology of the nanostructured Ni catalyst resulted in a higher biocrude yield of $36.63 \%$ and inhibited char formation, which was attributed to the $\mathrm{Ni}$ induced hydrogenation of biomass. However, both catalysts showed high catalytic activity to improve biocrude quality in terms of increasing $\mathrm{HHV}$ and $\mathrm{H} / \mathrm{C}$ ratio. The magnetic characteristics of both catalysts helped in easy recovery with an average recovery rate of $90 \%$.

For a broader view, the change in the energy recovery of the biocrude via heterogeneous catalysts from different feedstocks is illustrated in Figure 5.

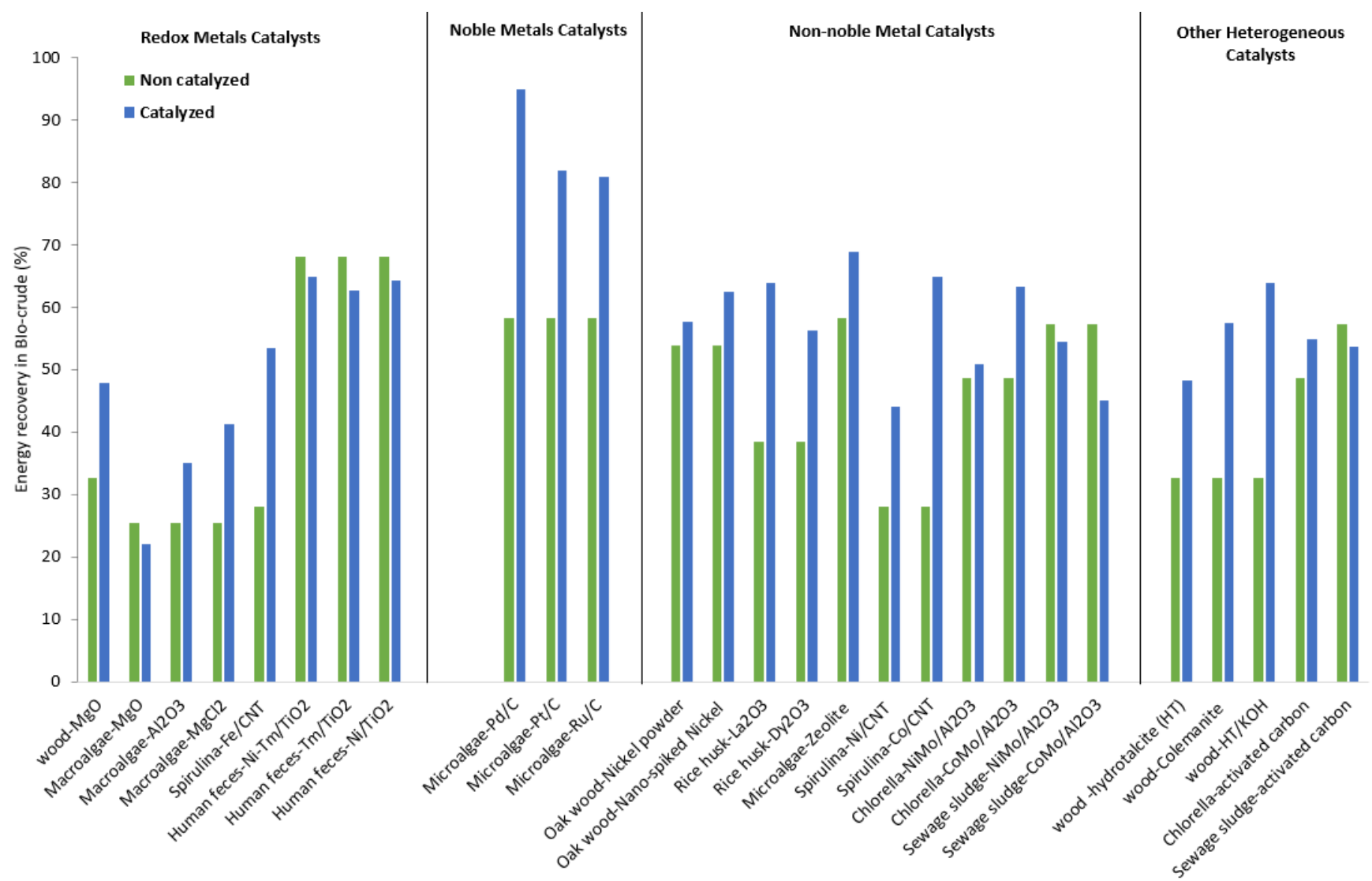

Figure 5. Effect of the heterogeneous catalyst on ER of biocrude from different feedstocks.

The deactivation of the catalyst mainly occurs due to the blocking of catalyst cavities via coking. The recovery of heterogeneous catalysts is very important for the sustainability of the HTL process. The recovery of heterogeneous catalysts is a tiresome process. Saber et al. utilized nano-Ni/SiO 2 and nano-zeolites for the HTL of microalgae and experienced a maximum of three times use for the HTL cycling process, as the nickel catalyst was recovered back about 62 and 18\% for the first and second recycle, respectively, and complete loss was recorded at the third cycle [113]. In conclusion, the usage of robust catalysts with efficient recycling/recovery approaches should be adopted to circumvent the catalytic deactivation, which could escalate the standards of HTL processing.

\subsection{Further Studies on Heterogeneous Catalysts}

Similar to homogenous catalysts (Section 3.3), many other studies are also available on heterogeneous catalysts. An account on them is presented in Table 4, where the most relevant aspects of some of the most recent studies are presented. 
Table 4. Major findings from HTL studies using heterogeneous catalysts.

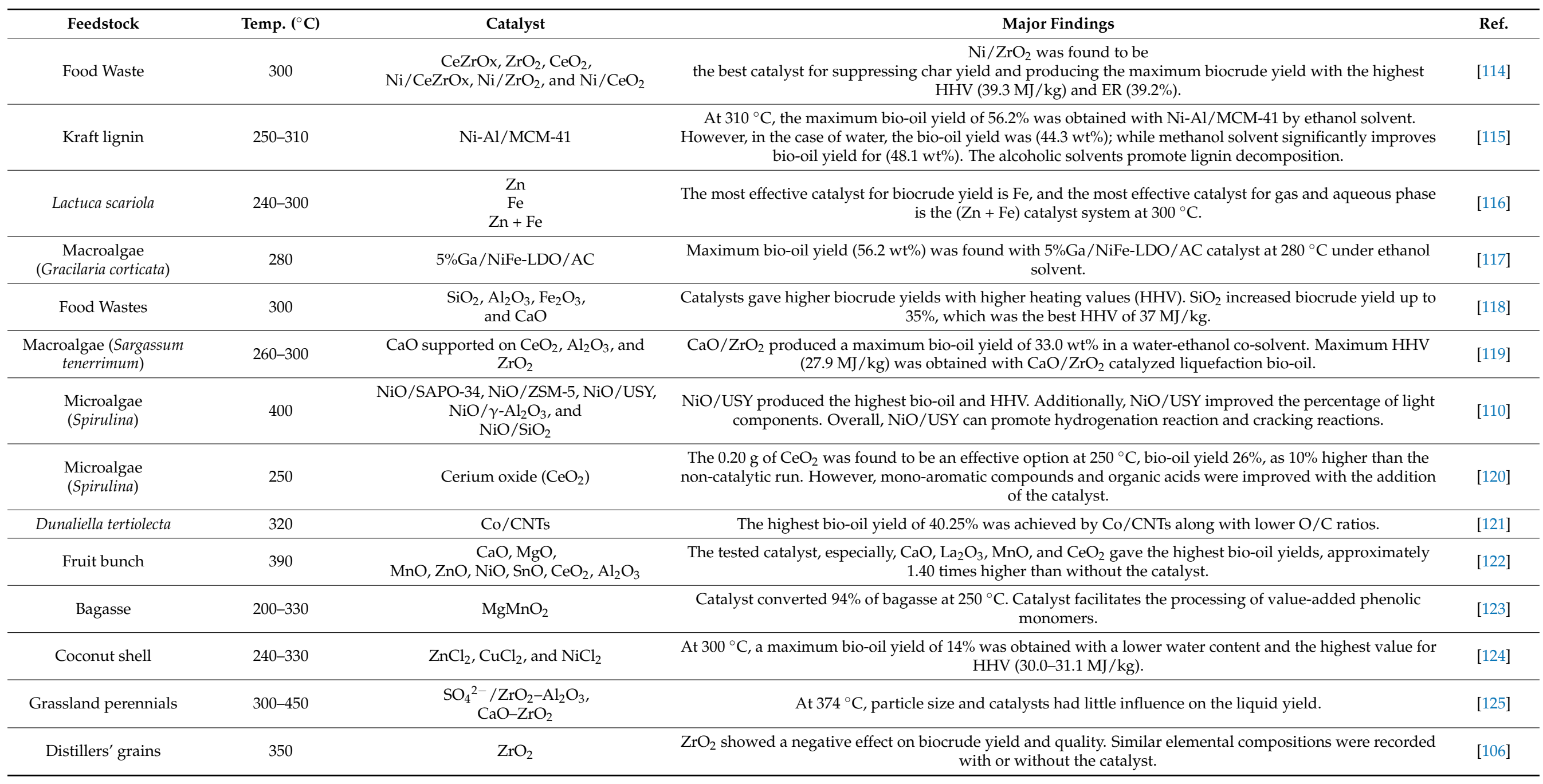




\subsection{Hydrothermal Stability of Heterogeneous Catalysts}

Catalyst stability is an important parameter regarding the process operation and economic performance. Stability of heterogeneous catalysts depends mainly on the surface functionalities, nature of support, and metal-support interactions. Under severe hydrothermal conditions, the concentration of the $\mathrm{H}^{+}$and $\mathrm{OH}^{-}$ions increases, which can affect the catalytic performance by attacking the surface of porous and hydrophilic supports (e.g., $\mathrm{Al}_{2} \mathrm{O}_{3}, \mathrm{SiO}_{2}, \mathrm{TiO}_{2}$, and carbon). These materials possess high surface area, thus they have been widely used in biomass conversion reactions. Chen et al. synthesized SBA-15 embedded with $\mathrm{Ni}, \mathrm{Pd}, \mathrm{Co}$, and Ru metals for catalytic HTL of microalgae at the different temperatures of 573, 593, and $613 \mathrm{~K}$ for $1 \mathrm{~h}$ [126]. Among all the transition metals, Co enhances the hydrothermal stability of SBA-15 due to the higher pore wall thickness of Co-SBA-15, which exhibited a high catalytic HTL performance with $78.78 \%$ of conversion and $24.11 \mathrm{wt} \%$ of bio-oil yield. However, the Pd-SAB-15 catalyst exhibited the poor hydrothermal stability for the catalytic HTL of microalgae. Previously, a series of $\mathrm{Ni} / \mathrm{CeO}_{2}$ catalysts were synthesized to evaluate their catalytic activity and hydrothermal stability for the HTL of rice straw [127]. The results indicated a higher thermal stability of $\mathrm{CeO}_{2}$ catalysts deposited with $\mathrm{Ni}$ nanoparticles than the pure $\mathrm{CeO}_{2}$ catalyst, as the $\mathrm{Ni} / \mathrm{CeO}_{2}$ catalyst possessed excellent cycling stability after the recovery. Furthermore, the catalyst showed higher biomass conversion rate and biocrude yield due to the high dispersion of $\mathrm{Ni}$ nanoparticles and stronger interactions between $\mathrm{Ni}$ and $\mathrm{CeO}_{2}$.

Additionally, carbon as a catalyst support has several advantages such as a high resistance to basic and acidic media, a high stability in aqueous media at high temperature as well as a high surface area and the possibility of enhancing its chemical surface properties by adding anchoring groups. The hydrothermal stability of $\mathrm{Ru} / \mathrm{C}$ catalyst was checked under supercritical water (SCW) conditions during the catalytic conversion of isopropanol [128]. It was found that a higher Ru dispersion was beneficial for the improvement in the catalytic activity. Furthermore, the carbon support appeared to be more thermally resistant after the SCWG treatment of isopropanol. However, the loss of catalytic activity of Ru/C catalyst was caused by the coke deposition. Huo et al. synthesized carbon-coated SBA-15 materials deposited with $\mathrm{Pd}$ nanoparticles for the hydrothermal treatment and aqueous-phase hydrogenation of furfural [129]. The Pd C/SBA-15 catalyst exhibited improved stability after the two separate treatments under hydrothermal conditions at $170{ }^{\circ} \mathrm{C}$ for $24 \mathrm{~h}$ as the structure of SBA-15 was unchanged and Pd sintering was successfully reduced.

Therefore, a basic understanding of the metal-support interactions and deactivation mechanisms will help to develop sustained catalytic materials for large-scale biomass conversion processes under hydrothermal conditions.

\section{Catalysis for HTL Biocrude Upgrading}

HTL biocrude is a diverse pool of unsaturated organics containing significant amounts of contaminants such as oxygen, nitrogen, and inorganics in higher amounts and sulfur in lower amounts. Inevitably, the presence of these organic contaminants makes HTL biocrude an intermediate product with high TAN, high viscosity/density, low $\mathrm{H} / \mathrm{C}$, and poor thermal stability. Therefore, a downstream refining step is essential before HTL biocrudes can be utilized for the production of drop-in fuels. To date, the removal of organic contaminants via catalytic hydrotreatment has been a widely explored research area. During catalytic hydrotreatment, the removal of inorganics, $\mathrm{O}, \mathrm{N}$, and $\mathrm{S}$ takes place with reactions involving hydrodemetallization (HDM), hydrodeoxygenation (HDO), decarboxylation, decarbonylation, hydrodenitrogenation (HDN), hydrodesulfurization (HDS), and hydrogenation (HYD) [54,130,131].

In the literature, researchers have largely utilized both non-sulfided and sulfided catalysts. Most of these studies have been carried out in batch units. The main purpose of these efforts was to demonstrate the practicability of hydroprocessing for the treatment of HTL biocrudes from different feedstocks (such as lignocellulosic residues, algae, sewage sludge etc.) toward the production of drop-in fuels. Moreover, these batch hydrotreating 
studies also documented the effect of different sulfided/non-sulfided catalysts and operating conditions. Likewise, both families of catalysts have also been tested to some extent in continuous units.

Hereafter, this section will comprehensively discuss and compare the effect of both non-sulfided and sulfided catalysts on the properties of hydrotreated oils (i.e., $\mathrm{H} / \mathrm{C}, \mathrm{O} / \mathrm{C}$, and $\mathrm{N} / \mathrm{C}$ atomic ratios). Details of batch hydrotreating studies that utilized different nonsulfided and sulfided catalysts are listed in Tables 5 and 6, respectively. The documented results of these batch hydrotreating studies are discussed and compared based on the fuel properties (such as $\mathrm{H} / \mathrm{C}, \mathrm{O} / \mathrm{C}$, and $\mathrm{N} / \mathrm{C}$ atomic ratios) in this section.

Table 5. Batch hydrotreatment of different HTL biocrudes in the presence of non-sulfided catalysts.

\begin{tabular}{|c|c|c|c|c|c|c|c|c|}
\hline \multirow{2}{*}{ HTL Biocrude } & \multirow{2}{*}{ Non-Sulfided Catalysts } & \multirow{2}{*}{$\begin{array}{c}\mathrm{T} \\
\left({ }^{\circ} \mathrm{C}\right)\end{array}$} & \multirow{2}{*}{$\frac{\mathbf{P}_{\mathrm{H} 2}}{(\mathrm{MPa})}$} & \multirow{2}{*}{$\begin{array}{c}\text { Time } \\
\text { (h) }\end{array}$} & \multicolumn{3}{|c|}{ Hydrotreated Oils } & \multirow{2}{*}{ Ref. } \\
\hline & & & & & $\mathrm{H} / \mathrm{C}$ & $\mathrm{N} / \mathrm{C}$ & $\mathrm{O} / \mathrm{C}$ & \\
\hline Chlorella pyrenoidosa & $\mathrm{Pt} / \mathrm{C}$ & 400 & 6 & 4 & 1.76 & 0.026 & 0.029 & [132] \\
\hline Chlorella pyrenoidosa & $\mathrm{Ru} / \mathrm{C}$ & 400 & 6 & 4 & 1.68 & 0.026 & 0.010 & [132] \\
\hline Chlorella pyrenoidosa & $\mathrm{Pd} / \mathrm{C}$ & 400 & 6 & 4 & 1.64 & 0.027 & 0.043 & [132] \\
\hline Chlorella pyrenoidosa & Activated carbon & 400 & 6 & 4 & 1.63 & 0.031 & 0.054 & [132] \\
\hline Chlorella pyrenoidosa & Raney-Ni & 400 & 6 & 4 & 1.77 & 0.017 & 0.031 & [132] \\
\hline Chlorella pyrenoidosa & $\mathrm{Ru} / \mathrm{C}+$ Raney-Ni & 400 & 6 & 4 & 1.74 & 0.021 & 0.018 & [132] \\
\hline Chlorella pyrenoidosa & $\mathrm{Ru} / \mathrm{C}: \mathrm{Pd} / \mathrm{C}$ & 400 & 6 & 4 & 2.06 & 0.020 & 0.030 & [133] \\
\hline Chlorella pyrenoidosa & $\mathrm{Ru} / \mathrm{C}: \mathrm{Pt} / \mathrm{C}$ & 400 & 6 & 4 & 1.83 & 0.026 & 0.008 & [133] \\
\hline Chlorella pyrenoidosa & $\mathrm{Ru} / \mathrm{C}: \mathrm{Pt} / \gamma-\mathrm{Al}_{2} \mathrm{O}_{3}$ & 400 & 6 & 4 & 1.73 & 0.019 & 0.040 & [133] \\
\hline Chlorella pyrenoidosa & $\mathrm{Ru} / \mathrm{C}: \mathrm{Rh} / \gamma-\mathrm{Al}_{2} \mathrm{O}_{3}$ & 400 & 6 & 4 & 1.80 & 0.025 & 0.028 & [133] \\
\hline Chlorella pyrenoidosa & $\mathrm{Ru} / \mathrm{C}: \mathrm{Mo}_{2} \mathrm{C}$ & 400 & 6 & 4 & 1.85 & 0.032 & 0.001 & [133] \\
\hline Chlorella pyrenoidosa & $\mathrm{Ru} / \mathrm{C}:$ Raney-Ni & 400 & 6 & 4 & 1.73 & 0.020 & 0.017 & [133] \\
\hline Chlorella pyrenoidosa & Ru/C:Activated carbon & 400 & 6 & 4 & 1.96 & 0.024 & 0.033 & [133] \\
\hline Chlorella pyrenoidosa & $\mathrm{Ru} / \mathrm{C}:$ Alumina & 400 & 6 & 4 & 1.87 & 0.026 & 0.004 & [133] \\
\hline Chlorella pyrenoidosa & $\mathrm{Pt} / \gamma-\mathrm{Al}_{2} \mathrm{O}_{3}$ & 400 & 6 & 1 & 1.48 & 0.051 & 0.053 & [134] \\
\hline Scenedesmus almeriensis & $\mathrm{Pt} / \gamma-\mathrm{Al}_{2} \mathrm{O}_{3}$ & 400 & 8 & 4 & 1.59 & 0.044 & 0.017 & [135] \\
\hline Nannochloropsis gaditana & $\mathrm{Pt} / \gamma-\mathrm{Al}_{2} \mathrm{O}_{3}$ & 400 & 8 & 4 & 1.67 & 0.024 & 0.014 & [135] \\
\hline Nannochloropsis sp. & $\mathrm{Ni} / \mathrm{C}$ & 350 & 6.9 & 10 & 1.59 & 0.018 & 0.003 & [136] \\
\hline Nannochloropsis sp. & $\mathrm{Ru} / \mathrm{C}$ & 350 & 6.9 & 10 & 1.72 & 0.014 & 0.009 & [136] \\
\hline Nannochloropsis sp. & $\mathrm{Pt} / \mathrm{C}$ & 350 & 6.9 & 10 & 1.59 & 0.013 & 0.005 & [136] \\
\hline Nannochloropsis sp. & $\mathrm{Ru} / \gamma-\mathrm{Al}_{2} \mathrm{O}_{3}$ & 400 & 5 & 1 & 1.66 & 0.033 & 0.04 & [137] \\
\hline Nannochloropsis sp. & $\mathrm{Pt} / \gamma-\mathrm{Al}_{2} \mathrm{O}_{3}$ & 400 & 5 & 1 & 1.77 & 0.030 & 0.014 & [137] \\
\hline Nannochloropsis sp. & $\mathrm{Pd} / \gamma-\mathrm{Al}_{2} \mathrm{O}_{3}$ & 400 & 5 & 1 & 1.72 & 0.035 & 0.025 & [137] \\
\hline Nannochloropsis sp. & $\mathrm{Pt} / \mathrm{C}$ & 400 & 5 & 1 & 1.76 & 0.034 & 0.018 & [137] \\
\hline Nannochloropsis sp. & $\mathrm{Ru} / \mathrm{C}$ & 400 & 5 & 1 & 1.76 & 0.037 & 0.034 & [137] \\
\hline Nannochloropsis sp. & $\mathrm{Pd} / \mathrm{C}$ & 400 & 5 & 1 & 1.75 & 0.034 & 0.058 & [137] \\
\hline Nannochloropsis sp. & $\mathrm{Ni}-\mathrm{Ru} / \mathrm{CeO}_{2}$ & 450 & 2 & 1 & 1.42 & 0.044 & 0.045 & [138] \\
\hline Nannochloropsis sp. & $\mathrm{Ni} / \mathrm{CeO}_{2}$ & 450 & 2 & 1 & 1.33 & 0.049 & 0.055 & [138] \\
\hline Chlorella & $\mathrm{NiMoW} / \mathrm{Al}_{2} \mathrm{O}_{3}$ & 400 & 3.4 & 4 & 1.38 & 0.059 & 0.067 & [139] \\
\hline Chlorella & $\mathrm{CoMoW} / \mathrm{Al}_{2} \mathrm{O}_{3}$ & 400 & 3.4 & 4 & 1.31 & 0.063 & 0.072 & [139] \\
\hline Chlorella & $\mathrm{CoNiMoW} / \mathrm{Al}_{2} \mathrm{O}_{3}$ & 400 & 3.4 & 4 & 1.43 & 0.056 & 0.065 & [139] \\
\hline Chlorella vulgaris & $\mathrm{NiW} / \mathrm{Al}_{2} \mathrm{O}_{3}$ & 400 & 13.9 & 4 & 1.62 & 0.042 & 0.013 & [140] \\
\hline Nannochloropsis gaditana & $\mathrm{NiW} / \mathrm{Al}_{2} \mathrm{O}_{3}$ & 400 & 13.9 & 4 & 1.75 & 0.047 & 0.024 & [140] \\
\hline Aspen wood & $\mathrm{NiW} / \mathrm{Al}_{2} \mathrm{O}_{3}$ & 350 & 7.5 & 2 & 1.20 & 0.006 & 0.062 & [141] \\
\hline Sweet sorghum bagasse & $\mathrm{Ru} / \mathrm{C}$ & 350 & 3.5 & 4 & 1.24 & 0.006 & 0.02 & [142] \\
\hline Duckweed (Lemna minor) & $\mathrm{Ru} / \mathrm{C}$ & 400 & 6 & 1 & 1.51 & 0.013 & 0.018 & [143] \\
\hline
\end{tabular}

\subsection{Non-Sulfided Catalysts in Batch Hydrotreating}

Bai et al. [132] carried out an extensive catalytic screening study by employing a wide range of different non-sulfided catalysts (such as $\mathrm{Pt} / \mathrm{C}, \mathrm{Ru} / \mathrm{C}, \mathrm{Pd} / \mathrm{C}$, activated carbon, Raney-Ni, and $\mathrm{Ru} / \mathrm{C}+$ Raney-Ni) to HTL biocrude from Chlorella pyrenoidosa algae under hydrotreating conditions. Their results showed that $\mathrm{Pt} / \mathrm{C}$ has the highest HYD activity (resulting in an increase in $\mathrm{H} / \mathrm{C}$ in the biocrude), $\mathrm{Ru} / \mathrm{C}$ has the highest $\mathrm{HDO}$, and Raney-Ni 
has the highest HDN. However, $\mathrm{Ru} / \mathrm{C}+$ Raney-Ni (two-component catalyst) exhibited optimal HYD, HDO, and HDN [132].

Based on these results, $\mathrm{Xu}$ et al. [133] further investigated two-component catalysts $(\mathrm{Ru} / \mathrm{C}+$ others metals) in 1:1 mass fraction. $\mathrm{Ru} / \mathrm{C}$ was employed in all experiments because of its proven ability of achieving higher $\mathrm{HDO}$. In comparison to a single-component catalyst (i.e., $\mathrm{Ru} / \mathrm{C}$ ), the two-component catalysts $(\mathrm{Ru} / \mathrm{C}: \mathrm{Pd} / \mathrm{C}, \mathrm{Ru} / \mathrm{C}: \mathrm{Pt} / \mathrm{C}, \mathrm{Ru} / \mathrm{C}: \mathrm{Pt} / \gamma$ $\mathrm{Al}_{2} \mathrm{O}_{3}, \mathrm{Ru} / \mathrm{C}: \mathrm{Rh} / \gamma-\mathrm{Al}_{2} \mathrm{O}_{3}, \mathrm{Ru} / \mathrm{C}: \mathrm{Mo}_{2} \mathrm{C}, \mathrm{Ru} / \mathrm{C}:$ Raney-Ni, $\mathrm{Ru} / \mathrm{C}$ :Activated carbon, and $\mathrm{Ru} / \mathrm{C}$ :Alumina) showed reduced coke yield, reduced gas formation, and increased HYD.

Duan et al. [134] studied the influence of catalyst loading on the properties of hydrotreated oils. They found out that with $40 \%$ catalyst loading, high HDN (low N/C) and high HDO (low O/C) were achieved [134]. Moreover, Barreiro et al. [135] reported the hydrotreatment of two different microalgae HTL biocrudes with $\mathrm{Pt} / \gamma-\mathrm{Al}_{2} \mathrm{O}_{3}$ catalyst. They noticed a reduction in the heteroatom content and an increase in volatility of both microalgae HTL biocrudes [135]. Shakya et al. [136] also reported the hydrotreatment of Nannochloropsis sp. algae with several non-sulfided catalysts (Ni/C, Ru/C and $\mathrm{Pt} / \mathrm{C}$ ). $\mathrm{Ru} / \mathrm{C}$ and $\mathrm{Pt} / \mathrm{C}$ resulted in a better oil quality in terms of HHV, HDN, and TAN. However, Ni/C showed the highest upgraded oil yields. They also observed a significant decrease in the pore volume and surface area of the catalysts $(\mathrm{Ni} / \mathrm{C}, \mathrm{Ru} / \mathrm{C}$, and $\mathrm{Pt} / \mathrm{C})$, primarily because of coke formation [136].

Patel et al. [137] carried out the hydrotreatment of algae biocrude in the presence of noble metal catalysts $(\mathrm{Pt}, \mathrm{Pd}$, and $\mathrm{Ru})$ with both carbon and $\gamma-\mathrm{Al}_{2} \mathrm{O}_{3}$ supports. They documented an improvement in $\mathrm{HDO}$ when the $\gamma-\mathrm{Al}_{2} \mathrm{O}_{3}$ support was added to $\mathrm{Pt}$ and $\mathrm{Ru}$ [137]. $\mathrm{Xu}$ et al. [138] investigated the hydrotreatment of algae biocrude with the $\mathrm{Ni}-\mathrm{Ru} / \mathrm{CeO}_{2}$ and $\mathrm{Ni} / \mathrm{CeO}_{2}$ catalysts. They recorded higher $\mathrm{HDS}$ for $\mathrm{Ni}-\mathrm{Ru} / \mathrm{CeO}_{2}$ and considered it as an optimal catalyst for the hydrotreatment of algal biocrude [138]. Xu et al. [139] explored the applicability of multi-metallic catalysts $\left(\mathrm{NiMoW} / \gamma-\mathrm{Al}_{2} \mathrm{O}_{3}, \mathrm{CoMoW} / \gamma-\mathrm{Al}_{2} \mathrm{O}_{3}\right.$, and $\mathrm{CoNiMoW} / \gamma-\mathrm{Al}_{2} \mathrm{O}_{3}$ ) during the hydrotreatment of Chlorella microalgae HTL biocrude. They noted that both $\mathrm{CoMoW} / \gamma-\mathrm{Al}_{2} \mathrm{O}_{3}$ and $\mathrm{CoNiMoW} / \gamma-\mathrm{Al}_{2} \mathrm{O}_{3}$ effectively reduced both the molecular weight distribution and boiling point distribution. Guo et al. [140] investigated the hydrotreatment of Chlorella vulgaris and Nannochloropsis gaditana HTL biocrudes in the $\mathrm{NiW} / \gamma-\mathrm{Al}_{2} \mathrm{O}_{3}$ catalyst and reported higher HDS activity in comparison to the conventional hydrotreating catalyst. Yu et al. [141] also explored the $\mathrm{NiW} / \gamma-\mathrm{Al}_{2} \mathrm{O}_{3}$ catalyst during the hydrotreatment of aspen wood HTL biocrude and recorded an increase in H/C, HHV, and HDO activity. Yue et al. [142] presented the hydrotreatment of sweet sorghum bagasse by utilizing $\mathrm{Ru} / \mathrm{C}$ as a $\mathrm{HDO}$ catalyst under mild operating conditions $\left(350^{\circ} \mathrm{C}\right.$ and 3.5 MPa). Furthermore, Duan et al. [143] utilized Ru on activated carbon (Ru/C) and successfully upgraded the duckweed HTL biocrude by reducing the heteroatom content and increasing the overall $\mathrm{H} / \mathrm{C}$ and $\mathrm{HHV}$.

\subsection{Sulfided Catalysts in Batch Hydrotreating}

Sulfided catalysts represent the state-of-the-art in hydrotreating and have been widely employed in fossil oil refineries for the desulfurization of oil fractions [144]. Sulfided catalysts are often represented by supported CoMo and NiMo. Although sulfur removal is generally not the main issue in biocrude hydrotreating, sulfided catalysts have also proven to be effective for the removal of other heteroatoms such as $\mathrm{O}$ and $\mathrm{N}$ as well as for hydrogenation.

Bai et al. [132] investigated sulfided $\mathrm{CoMo} / \gamma-\mathrm{Al}_{2} \mathrm{O}_{3}$ and $\mathrm{MoS}_{2}$ catalysts during the hydrotreatment of Chlorella pyrenoidosa algae HTL biocrude. Both sulfided catalysts reduced the heteroatom content and increased the $\mathrm{H} / \mathrm{C}$ and $\mathrm{HHV}$ of hydrotreated oils. During their investigation, they found that $\mathrm{CoMo} / \gamma-\mathrm{Al}_{2} \mathrm{O}_{3}$ tends to reduce coke formation compared to other non-sulfided catalysts [132]. Biller et al. [145] reported the hydrotreatment of HTL biocrude from Chlorella microalgae with conventional sulfided catalysts ( $\mathrm{CoMo} / \gamma$ $\mathrm{Al}_{2} \mathrm{O}_{3}$ and $\mathrm{NiMo} / \gamma-\mathrm{Al}_{2} \mathrm{O}_{3}$ ). They achieved higher $\mathrm{HDN}$ activity with sulfided NiMo and higher HDO activity with sulfided CoMo at given hydrotreating conditions $\left(405^{\circ} \mathrm{C}\right.$ and 
6.6 MPa) [145]. Jensen et al. [146] carried-out the hydrotreatment of hardwood biocrude with a commercial NiMo $/ \gamma-\mathrm{Al}_{2} \mathrm{O}_{3}$ catalyst. They found that the operating temperature and hydrogen to oil ratio had a positive influence on overall HYD and HDO. However, operating pressure mostly affects the HYD and HDO of low reactivity oxygenates [146]. Guo et al. [140] and $\mathrm{Yu}$ et al. [141] explored both non-sulfided $\mathrm{NiW} / \gamma-\mathrm{Al}_{2} \mathrm{O}_{3}$ and commercial sulfided $\mathrm{NiMo} / \gamma-\mathrm{Al}_{2} \mathrm{O}_{3}$ catalysts with Chlorella vulgaris/Nannochloropsis gaditana and aspen wood HTL biocrudes, respectively. Both of these separate studies showed higher $\mathrm{HDN}$ and $\mathrm{HDO}$ when the sulfided $\mathrm{NiMo} / \gamma-\mathrm{Al}_{2} \mathrm{O}_{3}$ catalyst was employed $[140,141]$. Zhao et al. [147,148] extensively investigated sulfided $\mathrm{NiMo} / \gamma-\mathrm{Al}_{2} \mathrm{O}_{3}$, both alone [147] and combined with the guard bed NiMo catalyst [148]. They evaluated a two-stage approach for effective catalytic hydrotreatment and successfully achieved higher HDY, HDO, and HDN.

Haider et al. [149] employed a sulfided $\mathrm{NiMo} / \gamma-\mathrm{Al}_{2} \mathrm{O}_{3}$ catalyst during the hydrotreatment of Spirulina microalgae biocrude and carried out a statistical analysis to evaluate the significance of the different process conditions. It was revealed that, up to $350{ }^{\circ} \mathrm{C}$, $\mathrm{HDO}$ is mainly temperature driven, while $\mathrm{HDN}$ is affected by both initial $\mathrm{H}_{2}$ pressure and pressure-temperature interaction. They also documented complete $\mathrm{HDO}$ at $350{ }^{\circ} \mathrm{C}$ and $8 \mathrm{MPa}$ [149]. Castello et al. [150] utilized sulfided $\mathrm{NiMo} / \gamma-\mathrm{Al}_{2} \mathrm{O}_{3}$ catalyst and studied the effect of different operating parameters on three different HTL biocrudes (Spirulina algae, sewage sludge, and Miscanthus). They achieved complete HDO for Spirulina algae and sewage sludge HTL biocrudes and reported a high extent of HDN. They found that higher hydrogen pressure is needed to prevent extensive coking and undesired decarboxylation reactions [150].

Rathsack et al. [151] and Zuber et al. [152] reported the hydrotreating of Chlorella vulgaris with sulfided $\mathrm{NiMo} / \gamma-\mathrm{Al}_{2} \mathrm{O}_{3}$ catalyst. They also achieved complete $\mathrm{HDO}$, lower $\mathrm{N} / \mathrm{C}(0.003)$, and higher H/C (1.91). Thanks to FT-ICR MS (Fourier-transform ion cyclotron resonance with mass spectrometry), they were able to conclude that $\mathrm{N}_{1}$ species are difficult to remove compared to $\mathrm{N}_{2}$ species [152]. Subagyono et al. [153] investigated sulfided NiMo/Al-SBA-15 as a catalyst for the hydrotreatment of microalgae HTL biocrude. During catalytic hydrotreatment with NiMo/Al-SBA-15, they attained high HYD, HDO, and HDN. In addition, they also realized that the acidity of the support material is directly related to product yield, while product quality is assured when NiMo is incorporated in the support material [153].

An important aspect is represented by the potential thermal instability of biocrude, which can seriously affect hydrotreating operations. Haider et al. [154] showed that HTL biocrudes are thermally unstable at high temperatures $\left(400^{\circ} \mathrm{C}\right)$ and they reported extensive coke formation upon directly subjecting these HTL biocrudes at these temperatures. They utilized a sulfided $\mathrm{NiMo} / \gamma-\mathrm{Al}_{2} \mathrm{O}_{3}$ catalyst in two-stages and ensured higher oil yields, higher $\mathrm{HDN}$, complete $\mathrm{HDO}$, and remarkable fuel properties with respect to $\mathrm{H} / \mathrm{C}$ and HHV [154].

Figure 6 illustrates the effect of non-sulfided and sulfided catalysts on the properties of the hydrotreated HTL biocrudes by means of van Krevelen-like plots. Sulfided catalysts perform better compared to non-sulfided ones under given hydrotreated conditions. HTL biocrudes treated with sulfided catalysts are on the extreme left side of both diagrams, meaning that the upgraded oil possesses a higher degree of HYD (highest $\mathrm{H} / \mathrm{C}$ atomic ratio) along with the highest $\mathrm{HDO}$ (lowest $\mathrm{O} / \mathrm{C}$ atomic ratio) and HDN (lowest N/C atomic ratio) activity. In contrast, non-sulfided noble metal catalysts were comparatively not conducive to enhanced HYD, HDO, and HDN activity. Thereby, non-sulfided noble metal catalysts retain a lower drop-in fuel properties. The lower efficiency of non-sulfided noble metal catalysts is probably due to the rapid catalyst deactivation due to sulfur molecules [95]. Similar concerns regarding sulfur poisoning of precious noble metal catalysts $(\mathrm{Pt}, \mathrm{Pd}, \mathrm{Rh}$, $\mathrm{Ru}$, etc.) are also suggested during the catalytic HDO of pyrolysis bio-oils where sulfur concentrations up to a few hundred ppm are found [155]. However, the short-term nature of batch hydrotreating HTL experiments does not allow for a correct evaluation of the deactivation mechanism by sulfur poisoning. 
Table 6. Batch hydrotreatment of different HTL biocrudes in the presence of sulfided catalysts.

\begin{tabular}{|c|c|c|c|c|c|c|c|c|}
\hline \multirow{2}{*}{ HTL Biocrude } & \multirow{2}{*}{ Sulfided Catalysts } & \multirow{2}{*}{$\frac{\mathrm{T}}{\left({ }^{\circ} \mathrm{C}\right)}$} & \multirow{2}{*}{$\frac{\mathbf{P}_{\mathrm{H} 2}}{(\mathbf{M P a})}$} & \multirow{2}{*}{$\begin{array}{c}\text { Time } \\
\text { (h) }\end{array}$} & \multicolumn{3}{|c|}{ Hydrotreated Oils } & \multirow{2}{*}{ Ref. } \\
\hline & & & & & $\mathrm{H} / \mathrm{C}$ & $\mathrm{N} / \mathrm{C}$ & $\mathrm{O} / \mathrm{C}$ & \\
\hline Chlorella pyrenoidosa & $\mathrm{MoS}_{2}$ & 400 & 6 & 4 & 1.68 & 0.031 & 0.044 & [132] \\
\hline Chlorella pyrenoidosa & $\mathrm{CoMo} / \gamma-\mathrm{Al}_{2} \mathrm{O}_{3}$ & 400 & 6 & 4 & 1.74 & 0.028 & 0.045 & [132] \\
\hline Chlorella & $\mathrm{NiMo} / \gamma-\mathrm{Al}_{2} \mathrm{O}_{3}$ & 405 & 6.6 & 2 & 1.64 & 0.024 & 0.013 & [145] \\
\hline Chlorella & $\mathrm{CoMo} / \gamma-\mathrm{Al}_{2} \mathrm{O}_{3}$ & 405 & 6.6 & 2 & 1.68 & 0.027 & 0.009 & [145] \\
\hline Hard wood & $\mathrm{NiMo} / \gamma-\mathrm{Al}_{2} \mathrm{O}_{3}$ & 350 & $14.7_{\max }$ & 2 & 1.67 & 0.004 & 0.003 & [146] \\
\hline Nannochloropsis oceanica & $\begin{array}{c}\mathrm{NiMo} / \gamma-\mathrm{Al}_{2} \mathrm{O}_{3}+ \\
\mathrm{NiMo} / \gamma-\mathrm{Al}_{2} \mathrm{O}_{3}\end{array}$ & $350+350$ & $4+4$ & $2+2$ & 1.85 & 0.021 & 0.007 & [147] \\
\hline Nannochloropsis oceanica & $\begin{array}{l}\text { NiMo guard catalyst } \\
\text { with } \mathrm{NiMo} / \gamma-\mathrm{Al}_{2} \mathrm{O}_{3}\end{array}$ & $350+350$ & $6+6$ & $1+1$ & 1.98 & 0.001 & 0.005 & [148] \\
\hline Aspen wood & $\mathrm{NiMo} / \gamma-\mathrm{Al}_{2} \mathrm{O}_{3}$ & 350 & 10 & 4 & 1.25 & 0.005 & 0.006 & [141] \\
\hline Spirulina & $\mathrm{NiMo} / \gamma-\mathrm{Al}_{2} \mathrm{O}_{3}$ & 375 & 7 & 3 & 1.79 & 0.031 & 0.000 & [149] \\
\hline Spirulina & $\mathrm{NiMo} / \gamma-\mathrm{Al}_{2} \mathrm{O}_{3}$ & 400 & 8 & 4 & 1.76 & 0.042 & 0.000 & [150] \\
\hline Sewage sludge & $\mathrm{NiMo} / \gamma-\mathrm{Al}_{2} \mathrm{O}_{3}$ & 400 & 8 & 4 & 1.95 & 0.009 & 0.000 & [150] \\
\hline Miscanthus & $\mathrm{NiMo} / \gamma-\mathrm{Al}_{2} \mathrm{O}_{3}$ & 400 & 8 & 4 & 1.45 & 0.015 & 0.007 & [150] \\
\hline Chlorella vulgaris & $\mathrm{NiMo} / \gamma-\mathrm{Al}_{2} \mathrm{O}_{3}$ & 400 & 12 & 9.9 & 1.91 & 0.003 & 0.000 & {$[151,152]$} \\
\hline Chlorococcum sp. & NiMo/Al-SBA-15 & 425 & 3 & 0.15 & 1.62 & 0.031 & 0.032 & [153] \\
\hline Spirulina & $\begin{array}{c}\mathrm{NiMo} / \gamma-\mathrm{Al}_{2} \mathrm{O}_{3}+ \\
\mathrm{NiMo} / \gamma-\mathrm{Al}_{2} \mathrm{O}_{3}\end{array}$ & $350+400$ & $8+8$ & $4+4$ & 2.07 & 0.006 & 0.000 & [154] \\
\hline Sewage sludge & $\begin{array}{l}\mathrm{NiMo} / \gamma-\mathrm{Al}_{2} \mathrm{O}_{3}+ \\
\mathrm{NiMo} / \gamma-\mathrm{Al}_{2} \mathrm{O}_{3}\end{array}$ & $350+400$ & $8+8$ & $4+4$ & 2.16 & 0.003 & 0.000 & [154] \\
\hline
\end{tabular}
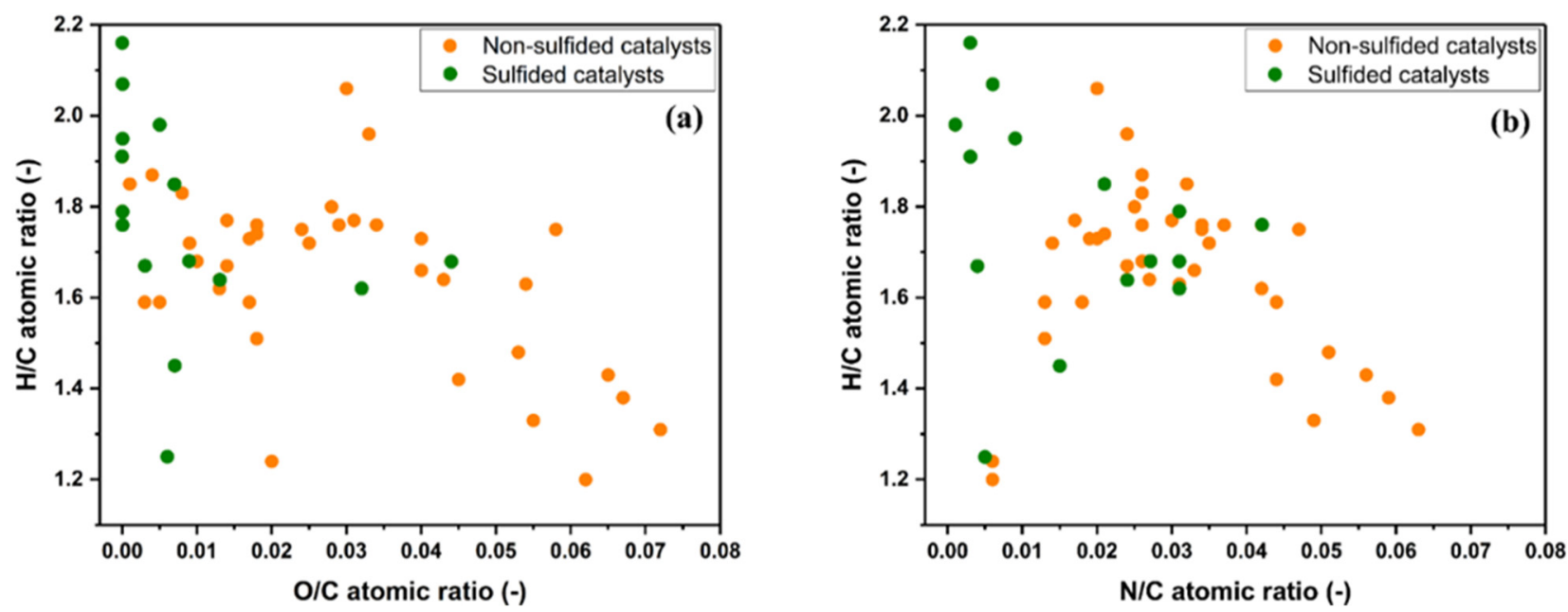

Figure 6. Van Krevelen diagram showing the atomic ratio of $\mathrm{H} / \mathrm{C}$ as a function of $\mathrm{O} / \mathrm{C}$ (a) and modified van Krevelen diagram with $\mathrm{H} / \mathrm{C}$ as a function of $\mathrm{N} / \mathrm{C}(\mathbf{b})$ of hydrotreated biocrudes with non-sulfided and sulfided catalysts. The atomic ratios are those reported in Tables 5 and 6.

\subsection{Catalysis in Continuous Hydrotreating}

Only a handful of continuous hydrotreating studies on HTL biocrudes are present in the open literature. Continuous processing indeed requires more complex facilities than batch units and, normally, also higher volumes of catalysts and biocrude feed. Continuous operations are, however, more significant toward the scale up of the process. Processing in a continuous unit may be substantially different from the batch, and results are often difficult to compare. Indeed, batch units often experience significant equilibrium and mass transfer limitations, which lead to lower performance compared to continuous operations in fixed beds or trickle beds.

All of the available continuous studies are carried-out in the presence of sulfided $\mathrm{CoMo} / \gamma-\mathrm{Al}_{2} \mathrm{O}_{3}$ and $\mathrm{NiMo} / \gamma-\mathrm{Al}_{2} \mathrm{O}_{3}$ hydrotreating catalysts (Table 5). However, only one continuous hydrotreating study [156] based on two-stage non-sulfided noble metal cata- 
lysts $\left(\mathrm{NiW} / \mathrm{SiO}_{2} / \mathrm{Al}_{2} \mathrm{O}_{3}\right.$ and $\left.\mathrm{Pd} / \mathrm{Al}_{2} \mathrm{O}_{3}\right)$ is available in the open literature. In his work, Jensen [156] carried out the catalytic hydrotreatment of HTL biocrude from forestry residue and employed two individual reactors, the former filled with $\mathrm{NiW} / \mathrm{SiO}_{2} / \mathrm{Al}_{2} \mathrm{O}_{3}$ and the latter with the $\mathrm{Pd} / \mathrm{Al}_{2} \mathrm{O}_{3}$ catalyst. Overall results showed poor $\mathrm{HDO}$, large exothermicity, and immediate reactor plugging. Subsequently, in the presence of the sulfided NiMo catalyst, Jensen was able to successfully operate for 660 hours on stream and also obtained complete HDO and higher H/C (1.73). Similarly, Haghighat et al. [157] also performed hydrotreatment of forestry residue HTL biocrude in a two-stage continuous unit. They utilized $\mathrm{CoMo} / \gamma-\mathrm{Al}_{2} \mathrm{O}_{3}$ in the first-stage and $\mathrm{NiMo} / \gamma-\mathrm{Al}_{2} \mathrm{O}_{3}$ in the second-stage and achieved $83.5 \% \mathrm{HDO}$ and $1.62 \mathrm{H} / \mathrm{C}$. Recently, Haider et al. conducted continuous upgrading of microalga Spirulina biocrude on $\mathrm{NiMo} / \mathrm{Al}_{2} \mathrm{O}_{3}$ by using $\mathrm{MoS}_{2}$ as a $\mathrm{HDM}$ catalyst in the upper part of the bed. Results showed complete deoxygenation and a large extent of denitrogenation. The proper selection of catalyst bed and operating conditions allowed for a continuous campaign to be conducted for around $335 \mathrm{~h}$ on stream, which was stopped only due to feed exhaustion.

Researchers from the Pacific Northwest National Laboratory (PNNL) accomplished the continuous hydrotreatment of HTL biocrudes by utilizing sulfided CoMo and NiMo catalysts. Elliott et al. [158] comprehensively investigated four different algal HTL biocrudes in a fixed-bed hydrotreating unit operating at continuous mode. After employing sulfided CoMo with fluorinated $\gamma-\mathrm{Al}_{2} \mathrm{O}_{3}$ support, they achieved good $\mathrm{HYD}(1.91-1.99 \mathrm{H} / \mathrm{C})$ and HDO (0.007-0.016 O/C), along with much higher HDN (0.001-0.003 N/C). Afterward, Albrecht et al. [159], Marrone et al. [160], and Collet et al. [161] employed CoMo as both the guard-bed HDM and bulk catalyst during the continuous hydrotreatment of algae, wastewater solids, and corn stover HTL biocrudes, respectively. They all achieved remarkable fuel properties with good HDO (0.008-0.015 O/C) and high HYD (1.93-2.02 H/C) and HDN (0.0003-0.002 N/C). Recently, PNNL investigated the continuous hydrotreatment of pine wood HTL biocrude [162] in a sulfided NiMo catalyst and sewage sludge HTL biocrude [163] in CoMo as the guard-bed HDM and NiMo as the bulk catalyst. By doing so, they obtained impressive drop-in fuel properties in the hydrotreated oils (Table 7).

Table 7. Continuous hydrotreatment of different HTL biocrudes in the presence of sulfided catalysts.

\begin{tabular}{|c|c|c|c|c|c|c|c|c|}
\hline \multirow{3}{*}{ HTL Biocrude } & \multicolumn{4}{|c|}{ Process parameters } & \multirow{2}{*}{\multicolumn{3}{|c|}{ Hydrotreated Oils }} & \multirow{3}{*}{ Ref. } \\
\hline & \multirow{2}{*}{ Sulfided Catalysts } & $\mathbf{T}$ & D & WHSVI & & & & \\
\hline & & $\left({ }^{\circ} \mathrm{C}\right)$ & (MPa) & $\left(h^{-1}\right)$ & $\mathrm{H} / \mathrm{C}$ & $\mathrm{N} / \mathrm{C}$ & $\mathrm{O} / \mathrm{C}$ & \\
\hline Nannochloropsis-Solix LEA & $\mathrm{CoMo} /$ fluorinated $-\mathrm{Al}_{2} \mathrm{O}_{3}$ & 405 & 13.6 & 0.14 LHSV & 1.99 & 0.001 & 0.007 & [158] \\
\hline Nannochloropsis-NB238 & CoMo/fluorinated- $\mathrm{Al}_{2} \mathrm{O}_{3}$ & 405 & 13.6 & 0.20 LHSV & 1.86 & 0.002 & 0.011 & [158] \\
\hline Nannochloropsis-Cellana LL & $\mathrm{CoMo} /$ fluorinated $-\mathrm{Al}_{2} \mathrm{O}_{3}$ & 405 & 13.6 & 0.20 LHSV & 1.91 & 0.003 & 0.016 & [158] \\
\hline Nannochloropsis-Celana HL & $\mathrm{CoMo} /$ fluorinated $-\mathrm{Al}_{2} \mathrm{O}_{3}$ & 405 & 13.6 & 0.20 LHSV & 1.98 & 0.001 & 0.015 & [158] \\
\hline Chlorella-Standard Lipid & CoMo guard bed with $\mathrm{CoMo} / \mathrm{Al}_{2} \mathrm{O}_{3}$ & 400 & 10.3 & 0.20 LHSV & 1.97 & 0.001 & 0.015 & [159] \\
\hline Chlorella-High Lipid & CoMo guard bed with $\mathrm{CoMo} / \mathrm{Al}_{2} \mathrm{O}_{3}$ & 400 & 10.3 & 0.20 LHSV & 2.02 & 0.0005 & 0.015 & [159] \\
\hline Primary sludge & CoMo guard bed with $\mathrm{CoMo} / \mathrm{Al}_{2} \mathrm{O}_{3}$ & 400 & 10.6 & 0.16 LHSV & 2.00 & 0.0003 & 0.010 & [160] \\
\hline Digested solids & CoMo guard bed with $\mathrm{CoMo} / \mathrm{Al}_{2} \mathrm{O}_{3}$ & 400 & 10.6 & 0.16 LHSV & 1.93 & 0.0006 & 0.008 & [160] \\
\hline Corn stover & CoMo guard bed with $\mathrm{CoMo} / \mathrm{Al}_{2} \mathrm{O}_{3}$ & 400 & 10.3 & 0.21 LHSV & 2.00 & 0.002 & 0.010 & [161] \\
\hline Forestry residues & $\mathrm{CoMo} / \gamma-\mathrm{Al}_{2} \mathrm{O}_{3}$ & 350 & 9.5 & 0.3 WHSV & 1.52 & - & 0.056 & [157] \\
\hline Forestry residues & $\mathrm{CoMo} / \gamma-\mathrm{Al}_{2} \mathrm{O}_{3}+\mathrm{NiMo} / \gamma-\mathrm{Al}_{2} \mathrm{O}_{3}$ & $\begin{array}{c}350+ \\
350\end{array}$ & $\begin{array}{c}9.5+ \\
9.5\end{array}$ & $\begin{array}{l}0.3+0.3 \\
\text { WHSV }\end{array}$ & 1.62 & - & 0.032 & [157] \\
\hline Pine wood & $\mathrm{NiMo} / \gamma-\mathrm{Al}_{2} \mathrm{O}_{3}$ & 400 & 12.4 & 0.10 LHSV & 1.60 & 0.0005 & 0.004 & [162] \\
\hline Sludge/Fog-GLWA & CoMo guard bed with $\mathrm{NiMo} / \mathrm{Al}_{2} \mathrm{O}_{3}$ & 400 & 10.3 & 0.39 WHSV & 2.03 & 0.001 & 0.009 & [163] \\
\hline Sludge-CCCSD & CoMo guard bed with $\mathrm{NiMo} / \mathrm{Al}_{2} \mathrm{O}_{3}$ & 400 & 10.3 & 0.39 WHSV & 2.00 & 0.007 & 0.004 & [163] \\
\hline Sludge/Fog-CCCSD & CoMo guard bed with $\mathrm{NiMo} / \mathrm{Al}_{2} \mathrm{O}_{3}$ & 400 & 10.3 & 0.39 WHSV & 2.12 & 0.001 & 0.004 & [163] \\
\hline Microalga Spirulina & $\mathrm{MoS}_{2}+\mathrm{NiMo} / \mathrm{Al}_{2} \mathrm{O}_{3}$ & 340 & 10.0 & 0.5 WHSV & 1.99 & 0.057 & - & [164] \\
\hline
\end{tabular}

${ }^{\mathrm{i}} \mathrm{WHSV}=$ Weight hourly space velocity; LHSV = Liquid hourly space velocity.

\section{Perspectives and Conclusions}

Catalysis is a fundamental aspect across the whole process chain related to biofuel production via HTL and hydrotreating. As was observed in the previous treatise, the 
presence of a catalyst turns out to be decisive in order to increase both the yield and the quality of the produced biocrude. The choice of whether to use a catalyst or not is still an option during HTL, although for several kinds of biomass, it represents an important aspect. On the other hand, hydrotreating intrinsically needs a proper catalyst to be carried out. In this latter case, it is important to define what kind of catalyst to adopt.

As far as HTL is concerned, the available results in the literature show that the performance of a catalyst is strongly affected by the type of biomass feedstock that is involved. This is especially true for homogeneous catalysis with alkali metals, for which there is an appreciable effect only for lignocellulosic feedstock. For other types of biomasses, the effects are negligible or even negative, with a reduction in the amounts of product. The composition of the biomass feed therefore plays an utmost role and this is a piece of information that needs proper consideration in light of establishing the process. In this regard, it is worth mentioning that each biomass feedstock contains a certain amount of inorganics, often involving different metal species. This is especially true for many residual biomasses (e.g., sewage sludge or agricultural residues), whereas woody biomass is often relatively poor in inorganics. The catalytic effect of the intrinsic metal content of biomass is a potentially interesting aspect for future studies. Moreover, in order to come to a rational design of the catalyst, it is necessary to perform fundamental mechanistic studies to obtain a better understanding of the different reaction pathways.

Due to the utilization of relatively economical catalysts and simplicity of implementation, homogeneous catalysis represents a viable and effective solution for HTL. However, an important aspect to be considered is that of catalyst recovery, in order to reduce the overall consumption. After the reaction, homogenous alkali catalysts are usually found in the aqueous phase, which should therefore be recirculated. However, metals and ions, in general, could also distribute among the other reaction products (char and biocrude). Knowledge about the amount and the form in which ions are found in each phase is very important. Moreover, the effect of residual amounts of inorganics in the biocrude should be considered, with attention to the possible consequences on downstream upgrading operations.

The utilization of heterogeneous catalysts can simplify the issue of catalyst recovery. However, this also strongly depends on the reactor technology that is adopted and on the catalyst itself. For the conditions typical of HTL, it is more likely to deal with the catalyst added to the slurry feed, therefore in the form of dispersed particles. In this case, recovery by gravity (settling) is strongly affected by viscosity and other rheological properties of the product mixture, which need to be properly investigated. Recovery of heterogeneous catalysts can be greatly enhanced by some properties of the catalyst itself (e.g., magnetic properties). In general, due to the cost of these materials, catalyst recovery plays a fundamental role in the economy of the process and therefore needs proper attention.

An interesting perspective is that of utilizing catalyst systems able to produce in situ hydrogen from water and make it available in the reaction. This can be achieved with zero-valent metals (ZVMs) that can be oxidized by water, generating hydrogen. Then, appropriate catalysts with specific activity for hydrogenation could greatly improve the quality of biocrude. The drawback of this approach resides in the energy needed to again reduce the metal oxides to ZVMs in order to restart the cycle. The availability of a cheap energy source, or the possibility of using side streams of the process (e.g., char) for the reduction process, is vital for this kind of approach.

Heterogeneous catalysts are able to show interesting results even for feedstocks for which alkali catalysts are not very effective. On the other hand, heterogeneous catalysts are often expensive and they can impact negatively on the economy of the process. An interesting perspective could be that of utilizing by-products of other industrial processes, for instance, metal-rich residues from metallurgic industries such as the so-called "red mud" from aluminum production.

As far as biocrude downstream processing is concerned, the utilization of a catalyst is necessary to conduct the process. As has been shown, traditional sulfided catalysts appear 
to be better performing than non-sulfided ones. It should, however, be pointed out that sulfided catalysts result from an almost century-long development process and therefore have reached a high level of technological maturity. One of the most important aspects of sulfided hydrotreating catalysts is their relatively high robustness, which makes them able to better tolerate impurities such as sulfur and nitrogen with respect to other catalysts. For this reason, sulfided catalysts seem to be a good choice when processing biomass-derived feedstocks, especially from non-lignocellulosic sources, where considerable amounts of sulfur can be present. However, the effect of biocrude origin (i.e., of the type of biomass used for its production) on the effectiveness of the upgrading catalyst needs to be analyzed and discussed in more depth.

On the other hand, sulfided catalysts can also be very negatively affected by the metals that are typically present in HTL biocrude. Levels usually recommended by manufacturers (i.e., below $50 \mathrm{ppm}$ of metals) cannot be normally achieved in biocrude, which requires the adoption of a strategy of demetallization to be achieved through pretreatment and/or the adoption of a hydrodemetallization (HDM) catalyst prior to the reactor bed. Demetallization is critical to prevent catalyst deactivation.

Even though non-sulfided catalysts appear less effective than sulfided ones in deoxygenation and denitrogenation, their usage could still be important for other upgrading treatments to improve certain properties of the final fuels such as isomerization or deep denitrogenation. Sulfided catalysts could therefore be utilized in the initial stages to remove the largest part of the contaminants, while non-sulfided catalysts might be beneficial in subsequent upgrading stages. This perspective is of high interest in the field.

In general, catalysis in the field of HTL and biocrude upgrading is receiving growing consideration. Progresses in this field will increase as far as more knowledge on the fundamental mechanisms of biomass and biocrude conversion is obtained. Therefore, obtaining better information on the fundamental mechanisms, for instance, by means of testing with model compounds, is important in order to advance the state-of-the-art and to find better catalysis strategies.

Author Contributions: Conceptualization. A.A.S., K.S., M.S.H., S.S.T., L.A.R., T.H.P. and D.C.; Methodology, D.C. and T.H.P.; Investigation, A.A.S., K.S., M.S.H. and S.S.T.; Data curation, A.A.S. and M.S.H.; Writing-original draft preparation, A.A.S., K.S., M.S.H., S.S.T. and D.C.; Writingreview and editing, D.C. and L.A.R. All authors have read and agreed to the published version of the manuscript.

Funding: This research received no external funding.

Data Availability Statement: Data are available on request.

Conflicts of Interest: The authors declare no conflict of interest.

\section{References}

1. Demirbas, A. Biorefineries: Current activities and future developments. Energy Convers. Manag. 2009, 50, 2782-2801. [CrossRef]

2. Huber, G.W.; Iborra, S.; Corma, A. Synthesis of Transportation Fuels from Biomass: Chemistry, Catalysts, and Engineering. Chem. Rev. 2006, 106, 4044-4098. [CrossRef]

3. Shahir, S.A.; Masjuki, H.H.; Kalam, M.A.; Imran, A.; Fattah, I.M.R.; Sanjid, A. Feasibility of diesel-biodiesel-ethanol/bioethanol blend as existing CI engine fuel: An assessment of properties, material compatibility, safety and combustion. Renew. Sustain. Energy Rev. 2014, 32, 379-395. [CrossRef]

4. Yang, J.; Caldwell, C.; Corscadden, K.; He, Q.S.; Li, J. An evaluation of biodiesel production from Camelina sativa grown in Nova Scotia. Ind. Crops Prod. 2016, 81, 162-168. [CrossRef]

5. Nigam, P.S.; Singh, A. Production of liquid biofuels from renewable resources. Prog. Energy Combust. Sci. 2011, 37, 52-68. [CrossRef]

6. Börjesson, P.I.I. Energy analysis of biomass production and transportation. Biomass Bioenergy 1996, 11, 305-318. [CrossRef]

7. Yang, L.; He, Q.S.; Corscadden, K.; Udenigwe, C.C. The prospects of Jerusalem artichoke in functional food ingredients and bioenergy production. Biotechnol. Rep. 2015, 5, 77-88. [CrossRef]

8. Huber, G.W.; Dumesic, J.A. An overview of aqueous-phase catalytic processes for production of hydrogen and alkanes in a biorefinery. Catal. Today 2006, 111, 119-132. [CrossRef] 
9. Peterson, A.a.; Vogel, F.; Lachance, R.P.; Fröling, M.; Antal, M.J., Jr.; Tester, J.W. Thermochemical biofuel production in hydrothermal media: A review of sub- and supercritical water technologies. Energy Environ. Sci. 2008, 1, 32. [CrossRef]

10. Castello, D.; Pedersen, T.H.; Rosendahl, L.A. Continuous Hydrothermal Liquefaction of Biomass: A Critical Review. Energies 2018, 11, 3165. [CrossRef]

11. Yang, J.; He, Q. (Sophia); Yang, L. A review on hydrothermal co-liquefaction of biomass. Appl. Energy 2019, 250, 926-945. [CrossRef]

12. Toor, S.S.; Rosendahl, L.; Rudolf, A. Hydrothermal liquefaction of biomass: A review of subcritical water technologies. Energy 2011, 36, 2328-2342. [CrossRef]

13. Huang, H.; Yuan, X. Recent progress in the direct liquefaction of typical biomass. Prog. Energy Combust. Sci. 2015, 49, 59-80. [CrossRef]

14. Dimitriadis, A.; Bezergianni, S. Hydrothermal liquefaction of various biomass and waste feedstocks for biocrude production: A state of the art review. Renew. Sustain. Energy Rev. 2017, 68, 113-125. [CrossRef]

15. Gollakota, A.R.K.; Kishore, N.; Gu, S. A review on hydrothermal liquefaction of biomass. Renew. Sustain. Energy Rev. 2018, 81, 1378-1392. [CrossRef]

16. Akhtar, J.; Amin, N.A.S. A review on process conditions for optimum bio-oil yield in hydrothermal liquefaction of biomass. Renew. Sustain. Energy Rev. 2011, 15, 1615-1624. [CrossRef]

17. Xue, Y.; Chen, H.; Zhao, W.; Yang, C.; Ma, P.; Han, S. A review on the operating conditions of producing bio-oil from hydrothermal liquefaction of biomass. Int. J. Energy Res. 2016, 40, 865-877. [CrossRef]

18. Scarsella, M.; de Caprariis, B.; Damizia, M.; De Filippis, P. Heterogeneous catalysts for hydrothermal liquefaction of lignocellulosic biomass: A review. Biomass Bioenergy 2020, 140, 105662. [CrossRef]

19. Kumar, M.; Olajire Oyedun, A.; Kumar, A. A review on the current status of various hydrothermal technologies on biomass feedstock. Renew. Sustain. Energy Rev. 2018, 81, 1742-1770. [CrossRef]

20. Elliott, D.C.; Biller, P.; Ross, A.B.; Schmidt, A.J.; Jones, S.B. Hydrothermal liquefaction of biomass: Developments from batch to continuous process. Bioresour. Technol. 2015, 178, 147-156. [CrossRef]

21. Zhu, Z.; Toor, S.S.; Rosendahl, L.; Chen, G. Analysis of product distribution and characteristics in hydrothermal liquefaction of barley straw in subcritical and supercritical water. Environ. Prog. Sustain. Energy 2014, 33, 737-743. [CrossRef]

22. Suzuki, A.; Nakamura, T.; Yokoyama, S.; Ogi, T.; Koguchi, K. Conversion of sewage sludge to heavy oil by direct thermochemical liquefaction. J. Chem. Eng. Jpn. 1988, 21, 288-293. [CrossRef]

23. Zhu, Z.; Rosendahl, L.; Toor, S.S.; Yu, D.; Chen, G. Hydrothermal liquefaction of barley straw to bio-crude oil: Effects of reaction temperature and aqueous phase recirculation. Appl. Energy 2015, 137, 183-192. [CrossRef]

24. Li, R.; Ma, Z.; Yang, T.; Li, B.; Wei, L.; Sun, Y. Sub-supercritical liquefaction of municipal wet sewage sludge to produce bio-oil: Effect of different organic-water mixed solvents. J. Supercrit. Fluids 2018, 138, 115-123. [CrossRef]

25. Xu, C.; Lancaster, J. Conversion of secondary pulp/paper sludge powder to liquid oil products for energy recovery by direct liquefaction in hot-compressed water. Water Res. 2008, 42, 1571-1582. [CrossRef] [PubMed]

26. Malins, K.; Kampars, V.; Brinks, J.; Neibolte, I.; Murnieks, R.; Kampare, R. Bio-oil from thermo-chemical hydro-liquefaction of wet sewage sludge. Bioresour. Technol. 2015, 187, 23-29. [CrossRef] [PubMed]

27. Seehar, T.H.; Toor, S.S.; Sharma, K.; Nielsen, A.H.; Pedersen, T.H.; Rosendahl, L.A. Influence of process conditions on hydrothermal liquefaction of eucalyptus biomass for biocrude production and investigation of the inorganics distribution. Sustain. Energy Fuels 2021, 5, 1477-1487. [CrossRef]

28. Shah, A.A.; Toor, S.S.; Conti, F.; Nielsen, A.H.; Rosendahl, L.A. Hydrothermal liquefaction of high ash containing sewage sludge at sub and supercritical conditions. Biomass Bioenergy 2020, 135, 105504. [CrossRef]

29. Biller, P.; Ross, A.B. Potential yields and properties of oil from the hydrothermal liquefaction of microalgae with different biochemical content. Bioresour. Technol. 2011, 102, 215-225. [CrossRef]

30. Shakya, R.; Whelen, J.; Adhikari, S.; Mahadevan, R.; Neupane, S. Effect of temperature and Na2CO3 catalyst on hydrothermal liquefaction of algae. Algal Res. 2015, 12, 80-90. [CrossRef]

31. Jindal, M.K.; Jha, M.K. Catalytic Hydrothermal Liquefaction of Waste Furniture Sawdust to Bio-oil. Indian Chem. Eng. 2016, 58, 157-171. [CrossRef]

32. Nazari, L.; Yuan, Z.; Souzanchi, S.; Ray, M.B.; Xu, C.C. Hydrothermal liquefaction of woody biomass in hot-compressed water: Catalyst screening and comprehensive characterization of bio-crude oils. Fuel 2015, 162, 74-83. [CrossRef]

33. Kaur, R.; Biswas, B.; Kumar, J.; Jha, M.K.; Bhaskar, T. Catalytic hydrothermal liquefaction of castor residue to bio-oil: Effect of alkali catalysts and optimization study. Ind. Crops Prod. 2020, 149, 112359. [CrossRef]

34. Zhang, B.; He, Z.; Chen, H.; Kandasamy, S.; Xu, Z.; Hu, X.; Guo, H. Effect of acidic, neutral and alkaline conditions on product distribution and biocrude oil chemistry from hydrothermal liquefaction of microalgae. Bioresour. Technol. 2018, 270, 129-137. [CrossRef]

35. Seehar, T.H.; Toor, S.S.; Shah, A.A.; Pedersen, T.H.; Rosendahl, L.A. Biocrude production from wheat straw at sub and supercritical hydrothermal liquefaction. Energies 2020, 13, 3114. [CrossRef]

36. Conti, F.; Toor, S.S.; Pedersen, T.H.; Seehar, T.H.; Nielsen, A.H.; Rosendahl, L.A. Valorization of animal and human wastes through hydrothermal liquefaction for biocrude production and simultaneous recovery of nutrients. Energy Convers. Manag. 2020, 216, 112925. [CrossRef] 
37. Toor, S.S.; Jasiunas, L.; Xu, C. (Charles); Sintamarean, I.M.; Yu, D.; Nielsen, A.H.; Rosendahl, L.A. Reduction of inorganics from macroalgae Laminaria digitata and spent mushroom compost (SMC) by acid leaching and selective hydrothermal liquefaction. Biomass Convers. Biorefin. 2018, 8, 369-377. [CrossRef]

38. Jensen, C.U.; Rosendahl, L.A.; Olofsson, G. Impact of nitrogenous alkaline agent on continuous HTL of lignocellulosic biomass and biocrude upgrading. Fuel Process. Technol. 2017, 159, 376-385. [CrossRef]

39. Jensen, C.U.; Rodriguez Guerrero, J.K.; Karatzos, S.; Olofsson, G.; Iversen, S.B. Fundamentals of Hydrofaction ${ }^{\text {TM}}$ : Renewable crude oil from woody biomass. Biomass Convers. Biorefin. 2017, 7, 495-509. [CrossRef]

40. Sintamarean, I.M.; Grigoras, I.F.; Jensen, C.U.; Toor, S.S.S.; Pedersen, T.H.; Rosendahl, L.A. Two-stage alkaline hydrothermal liquefaction of wood to biocrude in a continuous bench-scale system. Biomass Convers. Biorefin. 2017, 7, 425-435. [CrossRef]

41. Qian, L.; Wang, S.; Savage, P.E. Hydrothermal liquefaction of sewage sludge under isothermal and fast conditions. Bioresour. Technol. 2017, 232, 27-34. [CrossRef] [PubMed]

42. Ross, A.B.; Biller, P.; Kubacki, M.L.; Li, H.; Lea-Langton, A.; Jones, J.M. Hydrothermal processing of microalgae using alkali and organic acids. Fuel 2010, 89, 2234-2243. [CrossRef]

43. Xu, C.; Etcheverry, T. Hydro-liquefaction of woody biomass in sub- and super-critical ethanol with iron-based catalysts. Fuel 2008, 87, 335-345. [CrossRef]

44. Qu, Y.; Wei, X.; Zhong, C. Experimental study on the direct liquefaction of Cunninghamia lanceolata in water. Energy 2003, 28, 597-606. [CrossRef]

45. Conti, F.; Toor, S.S.; Pedersen, T.H.; Nielsen, A.H.; Rosendahl, L.A. Biocrude production and nutrients recovery through hydrothermal liquefaction of wastewater irrigated willow. Biomass Bioenergy 2018, 118, 24-31. [CrossRef]

46. He, C.; Wang, K.; Giannis, A.; Yang, Y.; Wang, J.Y. Products evolution during hydrothermal conversion of dewatered sewage sludge in sub- and near-critical water: Effects of reaction conditions and calcium oxide additive. Int. J. Hydrogen Energy 2015, 40, 5776-5787. [CrossRef]

47. Yokoyama, S.Y.; Suzuki, A.; Murakami, M.; Ogi, T.; Koguchi, K.; Nakamura, E. Liquid fuel production from sewage sludge by catalytic conversion using sodium carbonate. Fuel 1987, 66, 1150-1155. [CrossRef]

48. Shah, A.A.; Toor, S.S.S.; Seehar, T.H.; Nielsen, R.S.; Nielsen, A.H.; Pedersen, T.H.; Rosendahl, L.A. Bio-Crude Production through Aqueous Phase Recycling of Hydrothermal Liquefaction of Sewage Sludge. Energies 2020, 13, 493. [CrossRef]

49. Li, C.; Yang, X.; Zhang, Z.; Zhou, D.; Zhang, L.; Zhang, S.; Chen, J. Hydrothermal liquefaction of desert shrub salix psammophila to high value-added chemicals and hydrochar with recycled processing water. BioResources 2013, 8, 2981-2997. [CrossRef]

50. Yang, W.; Li, X.; Liu, S.; Feng, L. Direct hydrothermal liquefaction of undried macroalgae Enteromorpha prolifera using acid catalysts. Energy Convers. Manag. 2014, 87, 938-945. [CrossRef]

51. Prestigiacomo, C.; Costa, P.; Pinto, F.; Schiavo, B.; Siragusa, A.; Scialdone, O.; Galia, A. Sewage sludge as cheap alternative to microalgae as feedstock of catalytic hydrothermal liquefaction processes. J. Supercrit. Fluids 2019, 143, 251-258. [CrossRef]

52. Nagappan, S.; Bhosale, R.R.; Nguyen, D.D.; Chi, N.T.L.; Ponnusamy, V.K.; Woong, C.S.; Kumar, G. Catalytic hydrothermal liquefaction of biomass into bio-oils and other value-added products-A review. Fuel 2021, 285, 119053. [CrossRef]

53. Hao, B.; Xu, D.; Jiang, G.; Sabri, T.A.; Jing, Z.; Guo, Y. Chemical reactions in the hydrothermal liquefaction of biomass and in the catalytic hydrogenation upgrading of biocrude. Green Chem. 2021, 23, 1562-1583. [CrossRef]

54. Xu, D.; Lin, G.; Guo, S.; Wang, S.; Guo, Y.; Jing, Z. Catalytic hydrothermal liquefaction of algae and upgrading of biocrude: A critical review. Renew. Sustain. Energy Rev. 2018, 97, 103-118. [CrossRef]

55. Biller, P.; Johannsen, I.; dos Passos, J.S.; Ottosen, L.D.M. Primary sewage sludge filtration using biomass filter aids and subsequent hydrothermal co-liquefaction. Water Res. 2018, 130, 58-68. [CrossRef] [PubMed]

56. Singh, R.; Balagurumurthy, B.; Prakash, A.; Bhaskar, T. Catalytic hydrothermal liquefaction of water hyacinth. Bioresour. Technol. 2015, 178, 157-165. [CrossRef]

57. Singh, R.; Bhaskar, T.; Dora, S.; Balagurumurthy, B. Catalytic hydrothermal upgradation of wheat husk. Bioresour. Technol. 2013, 149, 446-451. [CrossRef]

58. Vardon, D.R.; Sharma, B.K.; Scott, J.; Yu, G.; Wang, Z.; Schideman, L.; Zhang, Y.; Strathmann, T.J. Chemical properties of biocrude oil from the hydrothermal liquefaction of Spirulina algae, swine manure, and digested anaerobic sludge. Bioresour. Technol. 2011, 102, 8295-8303. [CrossRef]

59. Chen, W.T.; Zhang, Y.; Zhang, J.; Schideman, L.; Yu, G.; Zhang, P.; Minarick, M. Co-liquefaction of swine manure and mixed-culture algal biomass from a wastewater treatment system to produce bio-crude oil. Appl. Energy 2014, 128, 209-216. [CrossRef]

60. Ding, X.; Subramanya, S.M.; Fang, T.; Guo, Y.; Savage, P.E. Effects of potassium phosphates on hydrothermal liquefaction of triglyceride, protein, and polysaccharide. Energy Fuels 2020, 34, 15313-15321. [CrossRef]

61. Qian, L.; Wang, S.; Xu, D.; Guo, Y.; Tang, X.; Wang, L. Treatment of sewage sludge in supercritical water and evaluation of the combined process of supercritical water gasification and oxidation. Bioresour. Technol. 2015, 176, 218-224. [CrossRef]

62. Kohansal, K.; Toor, S.; Sharma, K.; Chand, R.; Rosendahl, L.; Pedersen, T.H. Hydrothermal liquefaction of pre-treated municipal solid waste (biopulp) with recirculation of concentrated aqueous phase. Biomass Bioenergy 2021, 148, 106032. [CrossRef]

63. Pedersen, T.H.; Grigoras, I.F.; Hoffmann, J.; Toor, S.S.; Daraban, I.M.; Jensen, C.U.; Iversen, S.B.; Madsen, R.B.; Glasius, M.; Arturi, K.R.; et al. Continuous hydrothermal co-liquefaction of aspen wood and glycerol with water phase recirculation. Appl. Energy 2016, 162, 1034-1041. [CrossRef] 
64. Biller, P.; Riley, R.; Ross, A.B. Catalytic hydrothermal processing of microalgae: Decomposition and upgrading of lipids. Bioresour. Technol. 2011, 102, 4841-4848. [CrossRef]

65. Ali Shah, A.; Sohail Toor, S.; Hussain Seehar, T.; Sadetmahaleh, K.K.; Helmer Pedersen, T.; Haaning Nielsen, A.; Aistrup Rosendahl, L. Bio-crude production through co-hydrothermal processing of swine manure with sewage sludge to enhance pumpability. Fuel 2021, 288, 119407. [CrossRef]

66. Sintamarean, I.M.; Pedersen, T.H.; Zhao, X.; Kruse, A.; Rosendahl, L.A. Application of Algae as Cosubstrate to Enhance the Processability of Willow Wood for Continuous Hydrothermal Liquefaction. Ind. Eng. Chem. Res. 2017, 56, 4562-4571. [CrossRef]

67. Williams, P.J.L.B.; Laurens, L.M.L. Microalgae as biodiesel \& biomass feedstocks: Review \& analysis of the biochemistry, energetics \& economics. Energy Environ. Sci. 2010, 3, 554-590. [CrossRef]

68. Duan, P.; Savage, P.E. Upgrading of crude algal bio-oil in supercritical water. Bioresour. Technol. 2011, 102, 1899-1906. [CrossRef] [PubMed]

69. Zhu, Z.; Toor, S.S.; Rosendahl, L.; Yu, D.; Chen, G. Influence of alkali catalyst on product yield and properties via hydrothermal liquefaction of barley straw. Energy 2015, 80, 284-292. [CrossRef]

70. Yin, S.; Tan, Z. Hydrothermal liquefaction of cellulose to bio-oil under acidic, neutral and alkaline conditions. Appl. Energy 2012, 92, 234-239. [CrossRef]

71. Bi, Z.; Zhang, J.; Peterson, E.; Zhu, Z.; Xia, C.; Liang, Y.; Wiltowski, T. Biocrude from pretreated sorghum bagasse through catalytic hydrothermal liquefaction. Fuel 2017, 188, 112-120. [CrossRef]

72. Zhang, B.; Lin, Q.; Zhang, Q.; Wu, K.; Pu, W.; Yang, M.; Wu, Y. Catalytic hydrothermal liquefaction of Euglena sp. microalgae over zeolite catalysts for the production of bio-oil. RSC Adv. 2017, 7, 8944-8951. [CrossRef]

73. Zhang, J.; Chen, W.T.; Zhang, P.; Luo, Z.; Zhang, Y. Hydrothermal liquefaction of Chlorella pyrenoidosa in sub- and supercritical ethanol with heterogeneous catalysts. Bioresour. Technol. 2013, 133, 389-397. [CrossRef] [PubMed]

74. Zhuang, X.; Huang, Y.; Song, Y.; Zhan, H.; Yin, X.; Wu, C. The transformation pathways of nitrogen in sewage sludge during hydrothermal treatment. Bioresour. Technol. 2017, 245, 463-470. [CrossRef] [PubMed]

75. Liu, R.; Tian, W.; Kong, S.; Meng, Y.; Wang, H.; Zhang, J. Effects of inorganic and organic acid pretreatments on the hydrothermal liquefaction of municipal secondary sludge. Energy Convers. Manag. 2018, 174, 661-667. [CrossRef]

76. Chen, W.T.; Qian, W.; Zhang, Y.; Mazur, Z.; Kuo, C.T.; Scheppe, K.; Schideman, L.C.; Sharma, B.K. Effect of ash on hydrothermal liquefaction of high-ash content algal biomass. Algal Res. 2017, 25, 297-306. [CrossRef]

77. Chen, W.T.; Zhang, Y.; Zhang, J.; Yu, G.; Schideman, L.C.; Zhang, P.; Minarick, M. Hydrothermal liquefaction of mixed-culture algal biomass from wastewater treatment system into bio-crude oil. Bioresour. Technol. 2014, 152, 130-139. [CrossRef]

78. Ramos-Tercero, E.A.; Bertucco, A.; Brilman, D.W.F. Process water recycle in hydrothermal liquefaction of microalgae to enhance bio-oil yield. Energy Fuels 2015, 29, 2422-2430. [CrossRef]

79. Patel, B.; Guo, M.; Chong, C.; Sarudin, S.H.M.; Hellgardt, K. Hydrothermal upgrading of algae paste: Inorganics and recycling potential in the aqueous phase. Sci. Total Environ. 2016, 568, 489-497. [CrossRef]

80. He, Y.; Liang, X.; Jazrawi, C.; Montoya, A.; Yuen, A.; Cole, A.J.; Neveux, N.; Paul, N.A.; de Nys, R.; Maschmeyer, T.; et al. Continuous hydrothermal liquefaction of macroalgae in the presence of organic co-solvents. Algal Res. 2016, 17, 185-195. [CrossRef]

81. Yeh, T.M.; Dickinson, J.G.; Franck, A.; Linic, S.; Thompson, L.T., Jr.; Savage, P.E. Hydrothermal catalytic production of fuels and chemicals from aquatic biomass. J. Chem. Technol. Biotechnol. 2013, 88, 13-24. [CrossRef]

82. Kruse, A.; Maniam, P.; Spieler, F. Influence of proteins on the hydrothermal gasification and liquefaction of biomass. 2. Model compounds. Ind. Eng. Chem. Res. 2007, 46, 87-96. [CrossRef]

83. Hu, Y.; Feng, S.; Yuan, Z.; Xu, C. (Charles); Bassi, A. Investigation of aqueous phase recycling for improving bio-crude oil yield in hydrothermal liquefaction of algae. Bioresour. Technol. 2017, 239, 151-159. [CrossRef]

84. Hong, C.; Wang, Z.; Si, Y.; Li, Z.; Xing, Y.; Hu, J.; Li, Y. Effects of aqueous phase circulation and catalysts on hydrothermal liquefaction (HTL) of penicillin residue (PR): Characteristics of the aqueous phase, solid residue and bio oil. Sci. Total Environ. 2021, 776, 145596. [CrossRef]

85. Chacón-Parra, A.; Lewis, D.; van Eyk, P. The effect of ethanol as a homogeneous catalyst on the reaction kinetics of hydrothermal liquefaction of lipids. Chem. Eng. J. 2021, 414, 128832. [CrossRef]

86. Arun, J.; Gopinath, K.P.; SundarRajan, P.S.; Malolan, R.; Adithya, S.; Sai Jayaraman, R.; Srinivaasan Ajay, P. Hydrothermal liquefaction of Scenedesmus obliquus using a novel catalyst derived from clam shells: Solid residue as catalyst for hydrogen production. Bioresour. Technol. 2020, 310, 123443. [CrossRef]

87. Arturi, K.R.; Strandgaard, M.; Nielsen, R.P.; Søgaard, E.G.; Maschietti, M. The Journal of Supercritical Fluids Hydrothermal liquefaction of lignin in near-critical water in a new batch reactor: Influence of phenol and temperature. J. Supercrit. Fluids 2017, 123, 28-39. [CrossRef]

88. Mazaheri, H.; Lee, K.T.; Mohamed, A.R. Influence of temperature on liquid products yield of oil palm shell via subcritical water liquefaction in the presence of alkali catalyst. Fuel Process. Technol. 2013, 110, 197-205. [CrossRef]

89. Chang, C.C.; Chen, C.P.; Yang, C.S.; Chen, Y.H.; Huang, M.; Chang, C.Y.; Shie, J.L.; Yuan, M.H.; Chen, Y.H.; Ho, C.; et al. Conversion of waste bamboo chopsticks to bio-oil via catalytic hydrothermal liquefaction using K2CO3. Sustain. Environ. Res. 2016, 26, 262-267. [CrossRef] 
90. Déniel, M.; Haarlemmer, G.; Roubaud, A.; Weiss-Hortala, E.; Fages, J. Optimisation of bio-oil production by hydrothermal liquefaction of agro-industrial residues: Blackcurrant pomace (Ribes nigrum L.) as an example. Biomass Bioenergy 2016, 95, 273-285. [CrossRef]

91. Jena, U.; Das, K.C.; Kastner, J.R. Comparison of the effects of Na2CO3, Ca3(PO4)2, and NiO catalysts on the thermochemical liquefaction of microalga Spirulina platensis. Appl. Energy 2012, 98, 368-375. [CrossRef]

92. Biller, P.; Madsen, R.B.; Klemmer, M.; Becker, J.; Iversen, B.B.; Glasius, M. Effect of hydrothermal liquefaction aqueous phase recycling on bio-crude yields and composition. Bioresour. Technol. 2016, 220, 190-199. [CrossRef]

93. Wang, W.; Yu, Q.; Meng, H.; Han, W.; Li, J.; Zhang, J. Catalytic liquefaction of municipal sewage sludge over transition metal catalysts in ethanol-water co-solvent. Bioresour. Technol. 2018, 249, 361-367. [CrossRef]

94. Hirano, Y.; Miyata, Y.; Taniguchi, M.; Funakoshi, N.; Yamazaki, Y.; Ogino, C.; Kita, Y. Fe-assisted hydrothermal liquefaction of cellulose: Effects of hydrogenation catalyst addition on properties of water-soluble fraction. J. Anal. Appl. Pyrolysis 2020, 145, 104719. [CrossRef]

95. Duan, P.; Savage, P.E. Hydrothermal Liquefaction of a Microalga with Heterogeneous Catalysts. Ind. Eng. Chem. Res. 2011, 50, 52-61. [CrossRef]

96. Yildiz, G.; Ronsse, F.; Venderbosch, R.; van Duren, R.; Kersten, S.R.A.; Prins, W. Effect of biomass ash in catalytic fast pyrolysis of pine wood. Appl. Catal. B Environ. 2015, 168-169, 203-211. [CrossRef]

97. Xu, J.; Dong, X.; Wang, Y. Hydrothermal liquefaction of macroalgae over various solids, basic or acidic oxides and metal salt catalyst: Products distribution and characterization. Ind. Crops Prod. 2020, 151, 112458. [CrossRef]

98. Liu, B.; Wang, Z.; Feng, L. Effects of reaction parameter on catalytic hydrothermal liquefaction of microalgae into hydrocarbon rich bio-oil. J. Energy Inst. 2021, 94, 22-28. [CrossRef]

99. Wang, W.; Yang, L.; Yin, Z.; Kong, S.; Han, W.; Zhang, J. Catalytic liquefaction of human feces over Ni-Tm/TiO2 catalyst and the influence of operating conditions on products. Energy Convers. Manag. 2018, 157, 239-245. [CrossRef] [PubMed]

100. de Caprariis, B.; Bracciale, M.P.; Bavasso, I.; Chen, G.; Damizia, M.; Genova, V.; Marra, F.; Paglia, L.; Pulci, G.; Scarsella, M.; et al Unsupported Ni metal catalyst in hydrothermal liquefaction of oak wood: Effect of catalyst surface modification. Sci. Total Environ. 2020, 709, 136215. [CrossRef]

101. Shi, W.; Li, S.; Jin, H.; Zhao, Y.; Yu, W. The hydrothermal liquefaction of rice husk to bio-crude using metallic oxide catalysts. Energy Sources Part A Recover. Util. Environ. Eff. 2013, 35, 2149-2155. [CrossRef]

102. de Caprariis, B.; Bavasso, I.; Bracciale, M.P.; Damizia, M.; De Filippis, P.; Scarsella, M. Enhanced bio-crude yield and quality by reductive hydrothermal liquefaction of oak wood biomass: Effect of iron addition. J. Anal. Appl. Pyrolysis 2019, 139, 123-130. [CrossRef]

103. Miyata, Y.; Sagata, K.; Hirose, M.; Yamazaki, Y.; Nishimura, A.; Okuda, N.; Arita, Y.; Hirano, Y.; Kita, Y. Fe-Assisted Hydrothermal Liquefaction of Lignocellulosic Biomass for Producing High-Grade Bio-Oil. ACS Sustain. Chem. Eng. 2017, 5, 3562-3569. [CrossRef]

104. Zhao, B.; Hu, Y.; Qi, L.; Gao, J.; Zhao, G.; Ray, M.B.; Xu, C.C. Promotion effects of metallic iron on hydrothermal liquefaction of cornstalk in ethanol-water mixed solvents for the production of biocrude oil. Fuel 2021, 285, 119150. [CrossRef]

105. Maag, A.R.; Paulsen, A.D.; Amundsen, T.J.; Yelvington, P.E.; Tompsett, G.A.; Timko, M.T. Catalytic hydrothermal liquefaction of food waste using cezrox. Energies 2018, 11, 564. [CrossRef]

106. Christensen, P.R.; Mørup, A.J.; Mamakhel, A.; Glasius, M.; Becker, J.; Iversen, B.B. Effects of heterogeneous catalyst in hydrothermal liquefaction of dried distillers grains with solubles. Fuel 2014, 123, 158-166. [CrossRef]

107. Makhubela, B.C.E.; Darkwa, J. The Role of Noble Metal Catalysts in Conversion of Biomass and Bio-derived Intermediates to Fuels and Chemicals. Johnson Matthey Technol. Rev. 2018, 62, 4-31. [CrossRef]

108. Liu, S.; Amada, Y.; Tamura, M.; Nakagawa, Y.; Tomishige, K. One-pot selective conversion of furfural into 1,5-pentanediol over a Pd-added Ir-ReOx/SiO2 bifunctional catalyst. Green Chem. 2014, 16, 617-626. [CrossRef]

109. Paul, R.; Zhu, L.; Chen, H.; Qu, J.; Dai, L. Recent Advances in Carbon-Based Metal-Free Electrocatalysts. Adv. Mater. 2019, 31, 1-24. [CrossRef]

110. Wang, H.; Tian, W.; Zeng, F.; Du, H.; Zhang, J.; Li, X. Catalytic hydrothermal liquefaction of Spirulina over bifunctional catalyst to produce high-quality biofuel. Fuel 2020, 282, 118807. [CrossRef]

111. Luo, L.; Dai, L.; Savage, P.E. Catalytic hydrothermal liquefaction of soy protein concentrate. Energy Fuels 2015, 29 , 3208-3214. [CrossRef]

112. Yang, J.; Wang, D.; Han, H.; Li, C. Roles of cocatalysts in photocatalysis and photoelectrocatalysis. Acc. Chem. Res. 2013, 46, 1900-1909. [CrossRef] [PubMed]

113. Saber, M.; Golzary, A.; Hosseinpour, M.; Takahashi, F.; Yoshikawa, K. Catalytic hydrothermal liquefaction of microalgae using nanocatalyst. Appl. Energy 2016, 183, 566-576. [CrossRef]

114. Cheng, F.; Tompsett, G.A.; Fraga Alvarez, D.V.; Romo, C.I.; McKenna, A.M.; Niles, S.F.; Nelson, R.K.; Reddy, C.M.; GranadosFócil, S.; Paulsen, A.D.; et al. Metal oxide supported Ni-impregnated bifunctional catalysts for controlling char formation and maximizing energy recovery during catalytic hydrothermal liquefaction of food waste. Sustain. Energy Fuels 2021, 5, 941-955. [CrossRef]

115. Feng, L.; Li, X.; Wang, Z.; Liu, B. Catalytic hydrothermal liquefaction of lignin for production of aromatic hydrocarbon over metal supported mesoporous catalyst. Bioresour. Technol. 2021, 323, 124569. [CrossRef] 
116. Durak, H.; Genel, S. Catalytic hydrothermal liquefaction of lactuca scariola with a heterogeneous catalyst: The investigation of temperature, reaction time and synergistic effect of catalysts. Bioresour. Technol. 2020, 309, 123375. [CrossRef]

117. Li, Y.; Zhu, C.; Jiang, J.; Yang, Z.; Feng, W.; Li, L.; Guo, Y.; Hu, J. Catalytic hydrothermal liquefaction of Gracilaria corticata macroalgae: Effects of process parameter on bio-oil up-gradation. Bioresour. Technol. 2021, 319, 124163. [CrossRef]

118. Cheng, F.; Tompsett, G.A.; Murphy, C.M.; Maag, A.R.; Carabillo, N.; Bailey, M.; Hemingway, J.J.; Romo, C.I.; Paulsen, A.D.; Yelvington, P.E.; et al. Synergistic Effects of Inexpensive Mixed Metal Oxides for Catalytic Hydrothermal Liquefaction of Food Wastes. ACS Sustain. Chem. Eng. 2020, 8, 6877-6886. [CrossRef]

119. Biswas, B.; Kumar, A.; Fernandes, A.C.; Saini, K.; Negi, S.; Muraleedharan, U.D.; Bhaskar, T. Solid base catalytic hydrothermal liquefaction of macroalgae: Effects of process parameter on product yield and characterization. Bioresour. Technol. 2020, 307, 123232. [CrossRef] [PubMed]

120. Kandasamy, S.; Zhang, B.; He, Z.; Chen, H.; Feng, H.; Wang, Q.; Wang, B.; Ashokkumar, V.; Siva, S.; Bhuvanendran, N.; et al. Effect of low-temperature catalytic hydrothermal liquefaction of Spirulina platensis. Energy 2020, 190, 116236. [CrossRef]

121. Chen, Y.; Mu, R.; Yang, M.; Fang, L.; Wu, Y.; Wu, K.; Liu, Y.; Gong, J. Catalytic hydrothermal liquefaction for bio-oil production over CNTs supported metal catalysts. Chem. Eng. Sci. 2017, 161, 299-307. [CrossRef]

122. Yim, S.C.; Quitain, A.T.; Yusup, S.; Sasaki, M.; Uemura, Y.; Kida, T. Metal oxide-catalyzed hydrothermal liquefaction of Malaysian oil palm biomass to bio-oil under supercritical condition. J. Supercrit. Fluids 2017, 120, 384-394. [CrossRef]

123. Long, J.; Li, Y.; Zhang, X.; Tang, L.; Song, C.; Wang, F. Comparative investigation on hydrothermal and alkali catalytic liquefaction of bagasse: Process efficiency and product properties. Fuel 2016, 186, 685-693. [CrossRef]

124. Lee, J.H.; Hwang, H.; Moon, J.; Choi, J.W. Characterization of hydrothermal liquefaction products from coconut shell in the presence of selected transition metal chlorides. J. Anal. Appl. Pyrolysis 2016, 122, 415-421. [CrossRef]

125. Zhang, B.; von Keitz, M.; Valentas, K. Thermochemical liquefaction of high-diversity grassland perennials. J. Anal. Appl. Pyrolysis 2009, 84, 18-24. [CrossRef]

126. Chen, Y.; Wu, K.; Lin, Q.; Wu, Y.; Tang, Y.; Yang, M. Catalytic hydrothermal liquefaction of microalgae over metal incorporated mesoporous SBA-15 with high hydrothermal stability. Carbon Resour. Convers. 2018, 1, 251-259. [CrossRef]

127. Chen, D.; Ma, Q.; Wei, L.; Li, N.; Shen, Q.; Tian, W.; Zhou, J.; Long, J. Catalytic hydroliquefaction of rice straw for bio-oil production using Ni/CeO2 catalysts. J. Anal. Appl. Pyrolysis 2018, 130, 249-255. [CrossRef]

128. Peng, G.; Steib, M.; Gramm, F.; Ludwig, C.; Vogel, F. Synthesis factors affecting the catalytic performance and stability of Ru/C catalysts for supercritical water gasification. Catal. Sci. Technol. 2014, 4, 3329-3339. [CrossRef]

129. Huo, J.; Johnson, R.L.; Duan, P.; Pham, H.N.; Mendivelso-Perez, D.; Smith, E.A.; Datye, A.K.; Schmidt-Rohr, K.; Shanks, B.H. Stability of Pd nanoparticles on carbon-coated supports under hydrothermal conditions. Catal. Sci. Technol. 2018, 8, 1151-1160. [CrossRef]

130. Djandja, O.S.; Wang, Z.; Chen, L.; Qin, L.; Wang, F.; Xu, Y.; Duan, P. Progress in Hydrothermal Liquefaction of Algal Biomass and Hydrothermal Upgrading of the Subsequent Crude Bio-Oil: A Mini Review. Energy Fuels 2020, 34, 11723-11751. [CrossRef]

131. Chiaberge, S.; Siviero, A.; Passerini, C.; Pavoni, S.; Bianchi, D.; Haider, M.S.; Castello, D. Co-processing of Hydrothermal Liquefaction Sewage Sludge Biocrude with a Fossil Crude Oil by Codistillation: A Detailed Characterization Study by FTICR Mass Spectrometry. Energy Fuels 2021, 35, 13830-13839. [CrossRef]

132. Bai, X.; Duan, P.; Xu, Y.; Zhang, A.; Savage, P.E. Hydrothermal catalytic processing of pretreated algal oil: A catalyst screening study. Fuel 2014, 120, 141-149. [CrossRef]

133. Xu, Y.; Duan, P.; Wang, B. Catalytic upgrading of pretreated algal oil with a two-component catalyst mixture in supercritical water. Algal Res. 2015, 9, 186-193. [CrossRef]

134. Duan, P.; Bai, X.; Xu, Y.; Zhang, A.; Wang, F.; Zhang, L.; Miao, J. Catalytic upgrading of crude algal oil using platinum/gamma alumina in supercritical water. Fuel 2013, 109, 225-233. [CrossRef]

135. López Barreiro, D.; Gómez, B.R.; Ronsse, F.; Hornung, U.; Kruse, A.; Prins, W. Heterogeneous catalytic upgrading of biocrude oil produced by hydrothermal liquefaction of microalgae: State of the art and own experiments. Fuel Process. Technol. 2016, 148, 117-127. [CrossRef]

136. Shakya, R.; Adhikari, S.; Mahadevan, R.; Hassan, E.B.; Dempster, T.A. Catalytic upgrading of bio-oil produced from hydrothermal liquefaction of Nannochloropsis sp. Bioresour. Technol. 2018, 252, 28-36. [CrossRef]

137. Patel, B.; Arcelus-Arrillaga, P.; Izadpanah, A.; Hellgardt, K. Catalytic Hydrotreatment of algal biocrude from fast Hydrothermal Liquefaction. Renew. Energy 2017, 101, 1094-1101. [CrossRef]

138. Xu, D.; Guo, S.; Liu, L.; Hua, H.; Guo, Y.; Wang, S.; Jing, Z. Ni-Ru/CeO2 Catalytic Hydrothermal Upgrading of Water-Insoluble Biocrude from Algae Hydrothermal Liquefaction. Biomed Res. Int. 2018, 2018, 8376127. [CrossRef]

139. Xu, D.; Liu, L.; He, Z.; Yang, J.; Wu, Z.; Jing, Z. Hydrothermal upgrading of water-insoluble algal biocrude over $\gamma$-Al2O3 supported multi-metallic catalysts. J. Anal. Appl. Pyrolysis 2019, 140, 188-194. [CrossRef]

140. Guo, B.; Walter, V.; Hornung, U.; Dahmen, N. Hydrothermal liquefaction of Chlorella vulgaris and Nannochloropsis gaditana in a continuous stirred tank reactor and hydrotreating of biocrude by nickel catalysts. Fuel Process. Technol. 2019, 191, 168-180. [CrossRef]

141. Yu, J.; Biller, P.; Mamahkel, A.; Klemmer, M.; Becker, J.; Glasius, M.; Iversen, B.B. Catalytic hydrotreatment of bio-crude produced from the hydrothermal liquefaction of aspen wood: A catalyst screening and parameter optimization study. Sustain. Energy Fuels 2017, 1, 832-841. [CrossRef] 
142. Yue, Y.; Kastner, J.R.; Mani, S. Two-Stage Hydrothermal Liquefaction of Sweet Sorghum Biomass—Part II: Production of Upgraded Biocrude Oil. Energy Fuels 2018, 32, 7620-7629. [CrossRef]

143. Duan, P.; Zhang, C.; Wang, F.; Fu, J.; Lü, X.; Xu, Y.; Shi, X. Activated carbons for the hydrothermal upgrading of crude duckweed bio-oil. Catal. Today 2016, 274, 73-81. [CrossRef]

144. Furimsky, E. Hydroprocessing challenges in biofuels production. Catal. Today 2013, 217, 13-56. [CrossRef]

145. Biller, P.; Sharma, B.K.; Kunwar, B.; Ross, A.B. Hydroprocessing of bio-crude from continuous hydrothermal liquefaction of microalgae. Fuel 2015, 159, 197-205. [CrossRef]

146. Jensen, C.U.; Hoffmann, J.; Rosendahl, L.A. Co-processing potential of HTL bio-crude at petroleum refineries. Part 2: A parametric hydrotreating study. Fuel 2016, 165, 536-543. [CrossRef]

147. Zhao, B.; Wang, Z.; Liu, Z.; Yang, X. Two-stage upgrading of hydrothermal algae biocrude to kerosene-range biofuel. Green Chem. 2016, 18, 5254-5265. [CrossRef]

148. Zhao, B.; Shi, Z.; Yang, X. Upgrading Algae Biocrude for a Low-Nitrogen-Containing Biofuel: Compositions, Intermediates, and Reaction Routes. Ind. Eng. Chem. Res. 2017, 56, 6378-6390. [CrossRef]

149. Haider, M.; Castello, D.; Michalski, K.; Pedersen, T.; Rosendahl, L. Catalytic Hydrotreatment of Microalgae Biocrude from Continuous Hydrothermal Liquefaction: Heteroatom Removal and Their Distribution in Distillation Cuts. Energies 2018, 11, 3360. [CrossRef]

150. Castello, D.; Haider, M.S.; Rosendahl, L.A. Catalytic upgrading of hydrothermal liquefaction biocrudes: Different challenges for different feedstocks. Renew. Energy 2019, 141, 420-430. [CrossRef]

151. Rathsack, P.; Wollmerstaedt, H.; Kuchling, T.; Kureti, S. Analysis of hydrogenation products of biocrude obtained from hydrothermally liquefied algal biomass by comprehensive gas chromatography mass spectrometry (GC $\times$ GC-MS). Fuel 2019, 248, 178-188. [CrossRef]

152. Zuber, J.; Wollmerstädt, H.; Kuchling, T.; Kureti, S.; Rathsack, P. Analysis of Hydrogenation Products of Biocrude Obtained from Hydrothermally Liquefied Algal Biomass Using Fourier-Transform Ion Cyclotron Resonance Mass Spectrometry. Energy Fuels 2020, 34, 3199-3209. [CrossRef]

153. Subagyono, R.R.D.J.N.; Marshall, M.; Jackson, W.R.; Auxilio, A.R.; Fei, Y.; Chaffee, A.L. Upgrading Microalgal Biocrude Using NiMo/Al-SBA-15 as a Catalyst. Energy Fuels 2020, 34, 4618-4631. [CrossRef]

154. Haider, M.S.; Castello, D.; Rosendahl, L.A. Two-stage catalytic hydrotreatment of highly nitrogenous biocrude from continuous hydrothermal liquefaction: A rational design of the stabilization stage. Biomass Bioenergy 2020, 139, 105658. [CrossRef]

155. Elliott, D.C. Biofuel from fast pyrolysis and catalytic hydrodeoxygenation. Curr. Opin. Chem. Eng. 2015, 9, 59-65. [CrossRef]

156. Jensen, C.U. PIUS - Hydrofaction(TM) Platform with Integrated Upgrading Step. Ph.D. Thesis, Aalborg Universitetsforlag, Aalborg, Denmark, 2018.

157. Haghighat, P.; Montanez, A.; Aguilera, G.R.; Rodriguez Guerrero, J.K.; Karatzos, S.; Clarke, M.A.; McCaffrey, W. Hydrotreating of Hydrofaction $^{\mathrm{TM}}$ biocrude in the presence of presulfided commercial catalysts. Sustain. Energy Fuels 2019, 3, 744-759. [CrossRef]

158. Elliott, D.C.; Hart, T.R.; Schmidt, A.J.; Neuenschwander, G.G.; Rotness, L.J.; Olarte, M.V.; Zacher, A.H.; Albrecht, K.O.; Hallen, R.T.; Holladay, J.E. Process development for hydrothermal liquefaction of algae feedstocks in a continuous-flow reactor. Algal Res. 2013, 2, 445-454. [CrossRef]

159. Albrecht, K.O.; Zhu, Y.; Schmidt, A.J.; Billing, J.M.; Hart, T.R.; Jones, S.B.; Maupin, G.; Hallen, R.; Ahrens, T.; Anderson, D. Impact of heterotrophically stressed algae for biofuel production via hydrothermal liquefaction and catalytic hydrotreating in continuous-flow reactors. Algal Res. 2016, 14, 17-27. [CrossRef]

160. Marrone, P.A.; Elliott, D.C.; Billing, J.M.; Hallen, R.T.; Hart, T.R.; Kadota, P.; Moeller, J.C.; Randel, M.A.; Schmidt, A.J. Bench-scale evaluation of hydrothermal processing technology for conversion of wastewater solids to fuels. Water Environ. Res. 2018, 90, 329-342. [CrossRef] [PubMed]

161. Collett, J.R.; Billing, J.M.; Meyer, P.A.; Schmidt, A.J.; Remington, A.B.; Hawley, E.R.; Hofstad, B.A.; Panisko, E.A.; Dai, Z.; Hart, T.R.; et al. Renewable diesel via hydrothermal liquefaction of oleaginous yeast and residual lignin from bioconversion of corn stover. Appl. Energy 2019, 233-234, 840-853. [CrossRef]

162. Van Dyk, S.; Ebadian, M.; Su, J.; Larock, F.; Zhang, Y.; Monnier, J.; Wang, H.; Santosa, D.M.; Olarte, M.V.; Neuenschwander, G.; et al. Assessment of Likely Technology Maturation Pathways for Biojet Production from Forest Residues. Available online: https:/ / task39.sites.olt.ubc.ca/ files/2019/06/Executive-Summary-ATM-Project-26-June-2019.pdf (accessed on 18 July 2021).

163. Snowden-Swan, L.; Billing, J.; Thorson, M.; Schmidt, A.; Santosa, M.; Jones, S.; Hallen, R. Wet Waste Hydrothermal Liquefaction and Biocrude Upgrading to Hydrocarbon Fuels: 2019 State of Technology; Report no.: PNNL-29882; Pacific Northwest National Laboratory (PNNL): Richland, WA, USA, 2020.

164. Haider, M.S.; Castello, D.; Rosendahl, L.A. The Art of Smooth Continuous Hydroprocessing of Biocrudes Obtained from Hydrothermal Liquefaction: Hydrodemetallization and Propensity for Coke Formation. Energy Fuels 2021, 35, 10611-10622. [CrossRef] 